\title{
Differential effects of AMP-activated protein kinase in isolated rat atria subjected to simulated ischemia-reperfusion depending on the energetic substrates available
}

\author{
Romina Hermann ${ }^{1}$ - Victoria Evangelina Mestre Cordero ${ }^{1}$. \\ María de las Mercedes Fernández Pazos ${ }^{1}$ • Federico Joaquín Reznik ${ }^{1}$. \\ Débora Elisabet Vélez ${ }^{1}$ Enrique Alberto Savino ${ }^{1}$ • María Gabriela Marina Prendes ${ }^{1}$ • \\ Alicia Varela ${ }^{1}$
}

Received: 26 April 2017 /Revised: 24 September 2017 / Accepted: 28 September 2017 /Published online: 14 October 2017

(C) Springer-Verlag GmbH Germany 2017

\begin{abstract}
AMP-activated protein kinase (AMPK) is a serinethreonine kinase that functions primarily as a metabolic sensor to coordinate anabolic and catabolic processes in the cell, via phosphorylation of multiple proteins involved in metabolic pathways, aimed to re-establish energy homeostasis at a cellautonomous level. Myocardial ischemia and reperfusion represents a metabolic stress situation for myocytes. Whether AMPK plays a critical role in the metabolic and functional responses involved in these conditions remains uncertain. In this study, in order to gain a deeper insight into the role of endogenous AMPK activation during myocardial ischemia and reperfusion, we explored the effects of the pharmacological inhibition of AMPK on contractile function rat, contractile reserve, tissue lactate production, tissue ATP content, and cellular viability. For this aim, isolated atria subjected to simulated $75 \mathrm{~min}$ ischemia-75 min reperfusion (Is-Rs) in the presence or absence of the pharmacological inhibitor of AMPK (compound C) were used. Since in most clinical situations of ischemia-reperfusion the heart is exposed to high levels of fatty acids, the influence of palmitate present in the incubation medium was also investigated. The present results suggest that AMPK activity significantly increases during Is, remaining activated during Rs. The results support that intrinsic activation of AMPK has functional protective effects in the reperfused atria when glucose is the only available energetic substrate whereas it is deleterious when palmitate is also
\end{abstract}

Romina Hermann

rhermann@ffyb.uba.ar; romina_hermann@yahoo.com.ar

1 Physiology Unit, Department of Biological Sciences, School of Pharmacy and Biochemistry, University of Buenos Aires and IQUIMEFA-CONICET, Junín, 956 Buenos Aires, Argentina available. Cellular viability was not affected by either of these conditions.

Keywords AMP-activated protein kinase - Compound C . Atria $\cdot$ Simulated ischemia-reperfusion $\cdot$ Metabolism . Palmitate

\section{Introduction}

AMP-activated protein kinase (AMPK) is a serine-threonine kinase that functions as a cellular "fuel gauge" enzyme activated when cellular energy is depleted. This enzyme acts as an important regulator of diverse cellular pathways aimed to reestablish energy homeostasis at a cell-autonomous level. It promotes catabolic pathways that generate ATP, including breakdown of energy stores, glucose transport, glycolysis and fatty acid oxidation, and inhibits energy-consuming anabolic processes not essential for short-term cell survival. [25, 86]. It has also been proposed that AMPK promotes autophagy. Activation of this process may be protective by generation of metabolic substrates and removal of malfunctioning mitochondria or it may be harmful by induction of cell death [75, 76].

Mammalian AMPK is a heterotrimeric complex comprising a catalytic $\alpha$ subunit and regulatory $\beta$ and $\gamma$ subunits, each subunit being encoded by multiple genes $\left(\alpha_{1}, \alpha_{2}, \beta_{1}, \beta_{2}, \gamma_{1}\right.$, $\gamma_{2}, \gamma_{3}$ ). The heart predominantly expresses $\alpha_{2}$ (contributing $70-80 \%$ of the total AMPK catalytic activity), $\beta_{2}$, and both the $\gamma_{1}$ and $\gamma_{2}$ isoforms [68]. It has been demonstrated that cardiac AMPK is rapidly activated during ischemia [36, 37]. Under this condition, the increase of intracellular AMP/ATP ratio results in allosteric binding of AMP to the AMPK $\gamma$ 
subunit nucleotide-binding domains [55, 84]. Following this, the conformational change of the AMPK complex facilitates the subsequent phosphorylation of a critical residue at threonine $172\left(\mathrm{Thr}^{172}\right)$ in the $\alpha$ subunit by upstream kinases, such as the tumor suppressor kinase LKB1, which appears to be constitutively active [82]. Under normal aerobic conditions, physiologic concentrations of ATP antagonize this effect of AMP and decrease the suitability of AMPK for phosphorylation, keeping AMPK in the inactive state. In some cell types, phosphorylation of $\mathrm{Thr}^{172}$ could also occur through a different upstream enzyme, such as transforming growth factor- $\beta$ activated protein kinase-1 (TAK1) and calmodulindependent protein kinase kinase $\beta(\mathrm{CaMKK} \beta)$ activated by calcium ions, which appears to be particularly important in neurons, endothelial cells and T lymphocytes [50, 83].

Once AMPK is activated, it orchestrates several metabolic pathways to maintain acceptable ATP levels, required for cell survival under metabolic stress conditions. To this respect, AMPK plays an important role in regulating both fatty acid and glucose metabolism. Its activation results in a stimulation of glucose uptake, glycolysis, and fatty acid oxidation. AMPK promotes cellular glucose uptake by translocation of intracellular GLUT4-containing membrane vesicles to the sarcolemma and upregulation of GLUT1. AMPK also phosphorylates the 6-phosphofructo-2-kinase, resulting in the increase of fructose 2,6-bisphosphate, an allosteric activator of 6phosphofructo-1-kinase, which is an essential regulatory step in the glycolytic pathway $[48,66]$. Furthermore, AMPK also suppresses the activity of glycogen synthase, promoting the inhibition of glycogen synthesis, which also contributes to the conservation of ATP [23]. AMPK facilitates both fatty acid uptake and oxidation. This enzyme increases lipoprotein lipase translocation to vascular endothelial surface in the heart, promoting the release of fatty acids from circulating triacylglycerol, which is required for their delivery to cardiomyocytes [2]. In addition, AMPK also facilitates fatty acid uptake into cardiomyocytes through the recruitment of the fatty acid transporter CD36 to the sarcolemma [69]. Activated AMPK is also important for cytosolic fatty acid transport into the mitochondria and, consequently, for its oxidation. In this respect, AMPK phosphorylates and inactivates acetyl-CoA carboxylase, leading to a decrease in the intracellular concentration of malonyl-CoA, a negative regulator of carnitine palmitoyl transferase-I, the rate-limiting enzyme for mitochondrial fatty acid uptake and, therefore, for its oxidation [36].

While the activation of glucose uptake and glycolysis during ischemia has the potential to increase energy supply to the heart, fatty acid oxidation, which suppresses glucose oxidation via the Randle cycle [63], lead to uncoupling of glycolysis and glucose oxidation, proton accumulation, and a more acidic intracellular environment, which has been shown to be associated with a decrease in cardiac function during the critical period of reperfusion. Additionally, fatty acids require approximately $10-15 \%$ more oxygen to generate an equivalent amount of ATP when compared with glucose, making the heart especially vulnerable to damage following ischemia. Whether AMPK plays a critical role in the metabolic and functional responses to myocardial ischemia and reperfusion remains uncertain.

In this study, we determined the effects of endogenous AMPK activation in simulated ischemic-reperfused (Is-Rs) isolated rat atria. Many studies trying to elucidate the role of AMPK in the heart are being carried out employing isolated cardiomyocytes, being the murine atrial cardiomyocyte derived (HL-1) cell line one of the most widely used [16, 52, $65,69,71]$. Despite the parallel between the behavior of isolated myocytes and intact myocardium, whether the role of AMPK observed in single cells can be reproduced in the intact myocardial syncytium, where cell-cell junctions can modify cellular response as a result of metabolic and electrical communication in the tissue, still remains to be determined. Moreover, it is well known that left atria contribute significantly to total cardiac output with its reservoir, conduit, and pumping function [30], and recent studies suggest that left atrial ischemia might play important roles in the pathophysiology of atrial fibrillation [39, 57], common sustained arrhythmia encountered in clinical which is associated with increased mortality of ischemic-reperfused patients. The use of isolated atria in the present study provides new insights that might help to improve the understanding of the role played by AMPK in the response to ischemia and reperfusion in a more physiologically employable model, while also providing a deeper understanding into the effects of ischemia-reperfusion on atrial function, which are less well established but could provide important information to better understand ischemia-reperfusion injury.

Finally, since in most clinical situations of ischemia-reperfusion the heart muscle is exposed to high levels of fatty acids, the influence of free fatty acids, in the form of $1.2 \mathrm{mM}$ palmitate present in the incubation medium, on AMPK activation and effects was also investigated.

\section{Methods}

\section{Experimental protocol}

This study conformed to the Guide for the Care and Use of Laboratory Animals published by the US National Institutes of Health (NIH Publication No. 86-23, revised 1996; http:// oacu.od.nih.gov/regs/guide/guide 2011.pdf) and Argentine Law No. 14346 concerning animal protection.

Female Sprague-Dawley rats, weighing 220-270 g, fed ad libitum, and maintained on a 12-h dark/light cycle were used in this study. In order to carry out the experiments, rats were 
anesthetized by carbon dioxide inhalation, procedure wildly used as a safe form of anesthesia for short-term procedure. At concentrations above $70 \%$, carbon dioxide acts as an anesthetic agent that causes rapid loss of consciousness, due to the narcotic effect of the high intake of carbon dioxide on the brain without causing hypoxia, resulting in an effective and humane method for anesthesia and euthanasia of most small animals, with controversial effects on the heart rate but no serious disturbance to cardiac function [5, 14, 15, 22]. Afterwards, hearts were excised quickly and cooled in icecold saline until contractions stopped. Left atria were excised and mounted isometrically in $20 \mathrm{ml}$ organ baths at a resting force of $750 \mathrm{mg}$ and paced at $1 \mathrm{~Hz}$ with $5-10 \mathrm{~V}, 0.6 \mathrm{~ms}$ square pulses applied through bipolar punctate electrodes during the whole experiment. The bathing medium was a Krebs-Ringer bicarbonate solution of the following composition $(\mathrm{mM})$ : $\mathrm{NaCl}, 120 ; \mathrm{NaHCO}_{3}, 25 ; \mathrm{KCl}, 4.8 ; \mathrm{MgSO}_{4}, 1.33 ; \mathrm{KH}_{2} \mathrm{PO}_{4}$, 1.2; $\mathrm{CaCl}_{2}, 1.6$; and $\mathrm{Na}_{2}$ EDTA, 0.02 , continuously bubbled

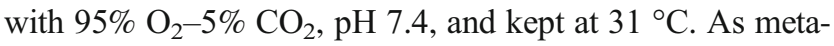
bolic substrates, the bathing medium contained $10 \mathrm{mM}$ D-glucose or $10 \mathrm{mM}$ D-glucose and $1.2 \mathrm{mM}$ palmitate prebound to $3 \%$ bovine serum albumin (BSA). Palmitate concentration was chosen according to plasma fatty acid levels measured within the first $30 \mathrm{~min}$ after the appearance of symptoms associated to the development of acute myocardial infarction, which would be due to an increase in catecholamine discharge along with plasma increase of glucocorticoids $[38,46]$.

After 60-min stabilization period, atria were subjected to 75-min Is followed by 75-min Rs. The duration of ischemia resulted in $\sim 40 \%$ functional recovery and $\sim 20 \%$ cell death, allowing demonstration of both beneficial and harmful effects in response to different interventions [28]. For the induction of Is, the medium was bubbled with $95 \% \mathrm{~N}_{2}-5 \% \mathrm{CO}_{2}(\mathrm{pH} 6.80$ 7.00) and metabolic substrates were replaced with $10 \mathrm{mM} 2-$ deoxy-D-glucose (Sigma). During Is, the $\mathrm{pO}_{2}$ of the bathing medium, measured polarimetrically in samples retrieved from the organ bath, was $67 \pm 5 \mathrm{mmHg}$. Rs was initiated by a buffer exchange to normoxic Krebs-Ringer bicarbonate solution. Stability of left atria paced at $1 \mathrm{~Hz}$ was maintained for at least $300 \mathrm{~min}$ in the Krebs-Ringer bicarbonate solution at $31^{\circ} \mathrm{C}$.

Ten-micromolar compound C, (6-[4-(2-piperidin-1-ylethoxy)phenyl]-3-pyridin-4-yl-pyrazolo[1,5-a]pyrimidine) (Sigma), a cell-permeant pyrrazolopyrimidine, the most widely pharmacological inhibitor of AMPK, was used. Compound C was added to the bathing medium at the onset of Is and maintained throughout the experiment. Stock solution was prepared in dimethylsulfoxide (DMSO) at a concentration not to exceed $0.1 \%$ DMSO $(v / v)$ in the final solution. The solvent did not show effects by itself in a separate experimental test carried out with isolated left atria (data not shown). Experiments conducted using variable ATP concentrations revealed that compound $\mathrm{C}$ is a potent and reversible inhibitor of AMPK, which is competitive with ATP, with $\mathrm{Ki}=109 \pm 16 \mathrm{nM}$ [88]. It has been demonstrated that compound $\mathrm{C}$ alters the conformation of the AMPK-activation loop and reduces the phosphorylation of Thr ${ }^{172}$ by AMPK kinases and/or promote the dephosphorylation of $\mathrm{Thr}^{172}$ by protein phosphatases [24, 49].

In a subset of experiments, $2 \mathrm{mM}$ oxfenicine (S-4hydroxyphenylglycine, Sigma), a carnitine palmitoyl transferase-I inhibitor, was added to the bathing medium at the onset of stabilization period and maintained until the end of the experiment.

\section{Western blotting}

Atria were homogenized in lysis buffer (18.2 mM HEPES, $1 \mathrm{mM}$ EDTA, $0.28 \mathrm{M}$ sucrose, $2 \mathrm{mM}$ dithiothreitol, $\mathrm{pH} 7.4$, $2 \mathrm{mM}$ phenylmethylsulfonyl fluoride, and $1 \times$ protease inhibitor cocktail from Thermo Scientific), an aliquot was saved to measure proteins by the method of Bradford et al. [8], and the remaining sample was subjected to SDS-PAGE.

Equal amounts of protein were mixed with LAEMMLI sample buffer (BioRad), boiled for $5 \mathrm{~min}$ and then resolved on $15 \%$ SDS-PAGE gels at $120 \mathrm{~V}$. Next, proteins were transferred to polyvinylidene difluoride membranes at $15 \mathrm{~V}$ for $50 \mathrm{~min}$ and then blocked for $1 \mathrm{~h}$ with 5\% non fat powder milk in Tris-buffered saline containing $0.1 \%$ Tween 20 (TBS-T). Membranes were then washed with TBS-T and incubated at $4{ }^{\circ} \mathrm{C}$ overnight with polyclonal rabbit anti-total AMPK $\alpha$ antibody (Thermo Scientific) at 1:1000, polyclonal rabbit antiphospho AMPK $\alpha \operatorname{Thr}^{172}$ antibody (Thermo Scientific) at 1:1000, and polyclonal rabbit anti- $\beta$-actin antibody (Thermo Scientific) at 1:1000 dilution. HRP-conjugated donkey antirabbit antibody (Thermo Scientific) at 1:250 dilution was then incubated for $2 \mathrm{~h}$ at room temperature. After TBS-T washes, bands were detected with Bio-Lumina detection reagent (Kalium Technologies) and exposed to an autoradiography film (Kodak). The films were scanned for band quantification using a Hewlett-Packard scanner and the intensity of the immunoblot bands was analyzed by densitometry using Image $\mathrm{J}$ software and normalized to $\beta$-actin. Results were expressed in arbitrary units.

\section{Measurement of atrial function}

Mechanical variables were recorded with stress transducers coupled to an amplifier and Grass polygraph. Systolic function was assessed by peak developed force $(F)$, peak rate of contraction $(+\mathrm{d} F / \mathrm{d} t)$, and force-time index (FTI), which reflects the mechanical energy of contraction per beat. Peak developed force was calculated as the difference between the peak of developed force curve and the resting force. FTI was obtained from the integration of the area under the systolic portion of the developed force curve. Diastolic function was assessed by developing contracture, measured as the rise in resting force, and the peak rate of relaxation $(-\mathrm{d} F / \mathrm{d} t)$. 
$F$, FTI, and $\pm \mathrm{d} F / \mathrm{d} t$ were expressed as a percentage of the respective basal values at the end of the 60-min aerobic stabilization period. The rise in resting force was expressed as a percentage of the peak developed force at the end of the 60min aerobic stabilization period.

\section{Contractile reserve}

Contractile reserve was assessed by the evaluation of maximal contractile response to a $\beta$-adrenergic agent. For this aim, $2 \mu \mathrm{M}$ isoproterenol (ISO, Sigma) was added to the incubation medium at the end of the Is-Rs period. The ISO dose, obtained from a dose-response curve previously performed in left atria subjected to incubation for $210 \mathrm{~min}$ in normal aerobic medium, elicited the maximal inotropic response. $F$, FTI, and $\pm \mathrm{d} F /$ $\mathrm{d} t$ values were expressed as a percentage of the respective value obtained at the end of the 60 -min stabilization period.

\section{Tissue lactate assay}

For determination of tissue lactate atria treated following the above described protocols were removed at the end of the 75min simulated ischemic period and immediately frozen between two blocks of ice at $-21^{\circ} \mathrm{C}$. Lactate was extracted from a 40- to 50-mg sample of frozen tissue, added to $6 \%$ ice-cold perchloric acid and measured enzymatically [72]. The results were expressed as $\mu \mathrm{mol}$ of lactate per gram of dry weight.

\section{Tissue ATP content}

Samples (40 mg) were homogenized in $500 \mu \mathrm{l}$ of $3 \%$ (mass/vol) cold perchloric acid for determination of tissue ATP. After removal of the denatured protein by centrifugation at $12,000 \times \mathrm{g}$ for $5 \mathrm{~min}$, aliquots of supernatant were neutralized with a mixture of $2 \mathrm{M} \mathrm{KOH}$ and $0.3 \mathrm{M}$ Mops [7]. Tissue ATP concentrations were determined on the neutralized supernatant by luciferin-luciferase luminometry (Sigma Chemiluminescent Assay kit).

Protein concentrations were determined in the solubilized pellet by the Lowry method [47]. The concentration of ATP was expressed as picomoles of ATP per milligram of tissue protein.

\section{Pyruvate dehydrogenase activity}

Mitochondria were isolated from simulated ischemic reperfused atria by differential centrifugation after tissue homogenization in ice-cold sucrose buffer solution (300 mM sucrose, $10 \mathrm{mM}$ Tris- $\mathrm{HCl}, 2 \mathrm{mM}$ EGTA, $5 \mathrm{mg} /$ $\mathrm{ml}$ BSA, $1 \mathrm{mM}$ phenylmethylsulfonyl fluoride, $\mathrm{pH}$ 7.4) [73]. The mitochondrial pellet was then washed three times in sucrose isolation buffer solution lacking BSA. Cardiac mitochondria prepared with this procedure have shown to be metabolically active, with respiratory control ratios of 3.5-
5.0 with succinate and of 8.0-10.0 with glutamate/malate, and corresponding adenosine diphosphate to oxygen ratios of 1.5-1.7 and 2.5-2.7 [73].

Pyruvate dehydrogenase activity was determined using a coupled enzyme reaction (Pyruvate Dehydrogenase Activity Assay Kit, Sigma). The enzymatic activity was determined by the reduction of $\mathrm{NAD}^{+}$to $\mathrm{NADH}$, coupled to the reduction of a reporter dye to yield a colored reaction product. The concentration of this product was monitored by measuring the increase in absorbance at $450 \mathrm{~nm}$, which is proportional to the enzymatic activity present. One unit of pyruvate dehydrogenase is the amount of enzyme that will generate $1 \mathrm{mmol} / \mathrm{min}$ of $\mathrm{NADH}$ at $37^{\circ} \mathrm{C}$.

Protein concentrations were determined in the solubilized pellet by the Lowry method [62]. PDH activity was expressed as namoles per minute (milliunits) per milligram of tissue protein.

\section{Measurement of cellular viability: MTT assay}

The reduction of 3-[4,5 dimethylthiazol-2yl]-2.5 diphenyltetrazolium bromide (MTT) (Sigma) to blue formazan by mitochondrial dehydrogenases was assessed at the end of each experimental protocol to measure cell viability.

Atria were loaded into a Falcon conical tube and incubated in $2 \mathrm{ml}$ of phosphate-buffer solution (PBS) containing $1 \mathrm{mg} / \mathrm{ml}$ MTT for $90 \mathrm{~min}$ at $37^{\circ} \mathrm{C}$. Atria were next transferred to $2 \mathrm{ml}$ PBS and shaken for $1 \mathrm{~min}$ to remove dye excess. Atria were then homogenized in $2 \mathrm{ml}$ DMSO at $9500 \mathrm{rpm}$ for $1 \mathrm{~min}$ and the homogenate was centrifuged at $1000 \times \mathrm{g}$ for $10 \mathrm{~min}$. The absorbance of the colored supernatant was then measured spectrophotometrically at $520 \mathrm{~nm}$ and optical density/mg wet weight of myocardial tissue was calculated [21]. The results were expressed as a percentage of the pre-ischaemic value.

\section{Statistical analysis}

All data are presented as mean \pm SEM. Changes in the contractile function were statistically compared using a two-factor ANOVA for repeated measures in one factor followed by Tukey's test. All biochemical parameters were evaluated using one or two-way ANOVA followed by Tukey's test. Statistical analysis was done using GraphPad Instat 4 (GraphPad Software, La Jolla, CA, USA). The probability level of 0.05 or lower was used as a criterion for biological significance.

\section{Results}

\section{AMPK immunoblotting}

We first examined whether Is and/or Rs activates the AMPK pathway in the isolated rat left atria. AMPK $\alpha$-subunit contains a serine-threonine kinase domain, which has a critical 
activating residue at $\mathrm{Thr}^{172}$ within the catalytic cleft. Phosphorylation status of this amino acid by upstream kinases is essential for AMPK activity and, therefore, it is widely used as an indicator of the activation state of the kinase [26]. In this context, we explored the ratio of phosphorylated $\alpha$-subunit in $\mathrm{Thr}^{172}$ (AMPK $\alpha$-pThr ${ }^{172}$ ) to total enzyme $\alpha$-subunit (AMPK $\alpha$-total), by Western blot analysis at $15-, 40-$, and 75-min Is and at 15-, 40-, and 75-min Rs. The results showed a significant increase in the AMPK $\alpha$-pThr ${ }^{172} / \mathrm{AMPK} \alpha$-total ratio during Is, reaching a maximum phosphorylation status at 40-min Is, which was sustained until the end of Is, either in the presence or absence of $1.2 \mathrm{mM}$ palmitate in the bathing medium during the 60-min stabilization period (Fig. 1a). During the 40-min Rs AMPK remained activated, either in the presence or absence of $1.2 \mathrm{mM}$ palmitate. However, at the end of Rs, the results showed a returned to baseline levels in both metabolic conditions (Fig. 1b). On the other hand, AMPK pharmacological inhibitor, compound $\mathrm{C}$, prevented phosphorylation in $\mathrm{Thr}^{172}$ during the whole experiment, either in the presence and absence of palmitate.

\section{Functional parameters}

As shown in Fig. 2, an abrupt decrease in the systolic parameters was observed in the first $10 \mathrm{~min}$ of Is. Following this early period, the decrease in these parameters occurred gradually. After 75-min Is, peak developed force and force-time index showed a slightly more pronounced decrease in the absence of compound $\mathrm{C}$, either in the presence and in the absence of $1.2 \mathrm{mM}$ palmitate in the bathing medium during the 60-min stabilization period. During the $75 \mathrm{~min}$ of Rs, contractile parameters gradually recovered. Atria subjected to Is-Rs in the presence of $1.2 \mathrm{mM}$ palmitate in the bathing medium during the 60-min stabilization period and 75-min Rs showed a decrease in the recovery of contractile function compared with atria incubated in the presence of glucose as sole exogenous substrate. AMPK inhibitor did not affect systolic function recovery in either metabolic condition.

Figure 3 shows that maximum ischemic contracture developed earlier in the atria stabilized with glucose and palmitate, compared with atria stabilized in the presence of glucose as sole exogenous substrate $(20$ - vs 40 -min Is, $p<0.05)$. Compound $\mathrm{C}$ did not affect the development of ischemic contracture when the atria were stabilized with glucose only. However, in the experiments stabilized with glucose and palmitate as exogenous substrates, the addition of compound $\mathrm{C}$ increased maximum ischemic contracture, without affecting the time when this peak appeared (Fig. 3b). On the other hand, during simulated ischemia compound $\mathrm{C}$ generated a less pronounced decrease in the relaxation rate, either in the presence of glucose as sole exogenous substrate or glucose and palmitate during 60-min aerobic stabilization period. After 75-min Rs, atria subjected to Is-Rs in the presence of $1.2 \mathrm{mM}$ palmitate in the bathing medium during the 60 -min stabilization period and 75-min Rs showed a decrease in the recovery of peak rate of relaxation compared with atria incubated in the presence of glucose as sole exogenous substrate. Compound $\mathrm{C}$ reversed the harmful effect of palmitate over this functional parameter.

In order to investigate the ability of the surviving myocardium to increase its level of contractile function in situations of increased energy demand, inotropic stimulation with ISO was assessed. As expected for normal myocardium, atria subjected to the 60 -min stabilization period or to $210 \mathrm{~min}$ of aerobic conditions developed a similar increase in contractile parameters in response to $\beta$-adrenergic stimulation. This increase in cardiac contractility was attenuated in atria subjected to Is-Rs. This effect was even more pronounced in the experiments performed in the presence of glucose and palmitate as exogenous substrates. Compound $\mathrm{C}$ reversed the harmful effects in myocardial contractility as a response to $\beta$-adrenergic stimulation in the atria subjected to ischemia-reperfusion in the presence of palmitate. However, in the presence of glucose as sole exogenous substrate, the AMPK inhibitor attenuated the response to ISO even more (Fig. 4).

To assess the influence of palmitate oxidation in the present contractile results, oxfenicine ( $2 \mathrm{mM})$, a carnitine palmitoyl transferase-I inhibitor, was used for the limitation of mitochondrial fatty acid uptake rate and therefore its oxidation. The results showed that oxfenicine reversed the harmful effects of palmitate on functional recovery, while in the atria subjected to Is-Rs in the presence of glucose as sole exogenous substrate the contractile reserve was reduced by oxfenicine similarly to that observed in the presence of compound $\mathrm{C}$ (Table 1).

\section{Lactate tissue content}

It has been reported that AMPK stimulates glucose transport and glycolysis during ischemia, which are particularly important for metabolic adaptation under this condition. However, during ischemia, glycolysis becomes uncoupled from glucose oxidation, resulting in the accumulation of deleterious byproducts of glycolysis within the cardiac cells. This can lead to the redirection of ATP away from myocardial contraction and toward the clearance of glycolytic by-products, leading to a decrease in both cardiac function and efficiency [17, 41, 42]. To assess if these metabolic pathways are enhanced by AMPK during ischemia, tissue lactate content, the final product of glycolysis under ischemic condition, was measured at the end of this period. Results showed that after aerobic incubation in the presence of $1.2 \mathrm{mM}$ palmitate lactate accumulation was reduced (Fig. 5). Atria subjected to Is in the presence of compound $\mathrm{C}$, performed either in the presence of glucose as sole exogenous substrate or glucose and palmitate during 60min aerobic stabilization period, showed an even more 
a
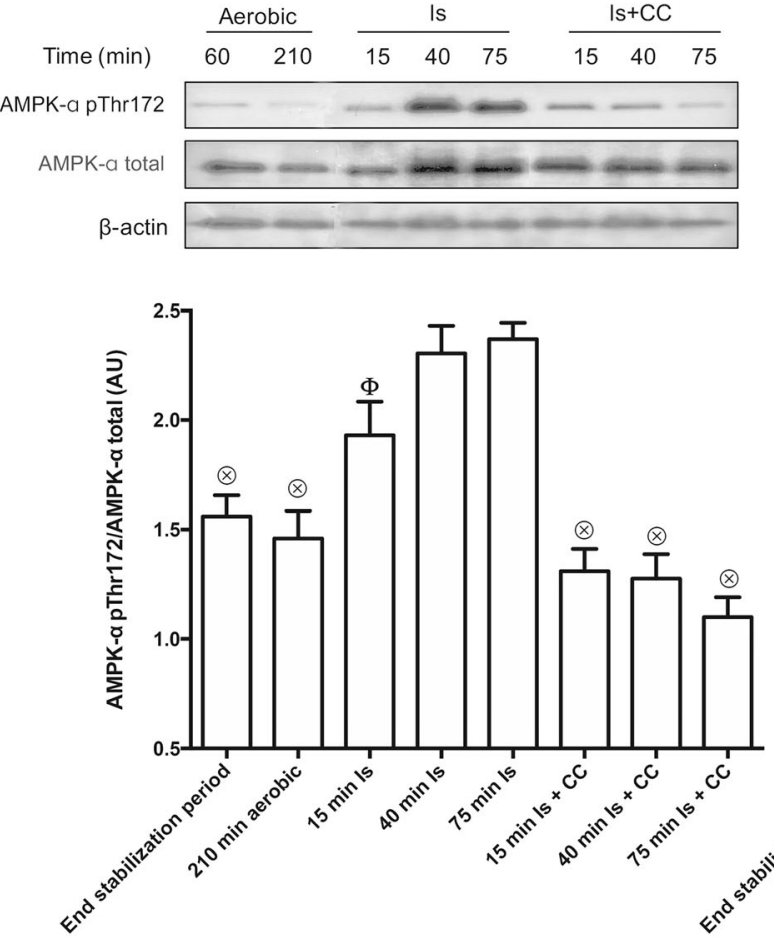
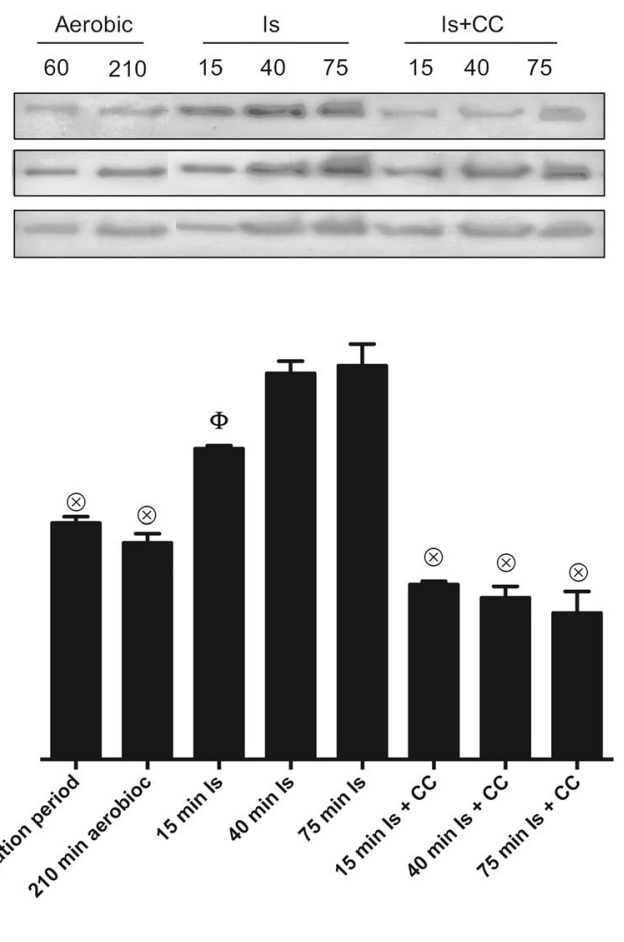

b
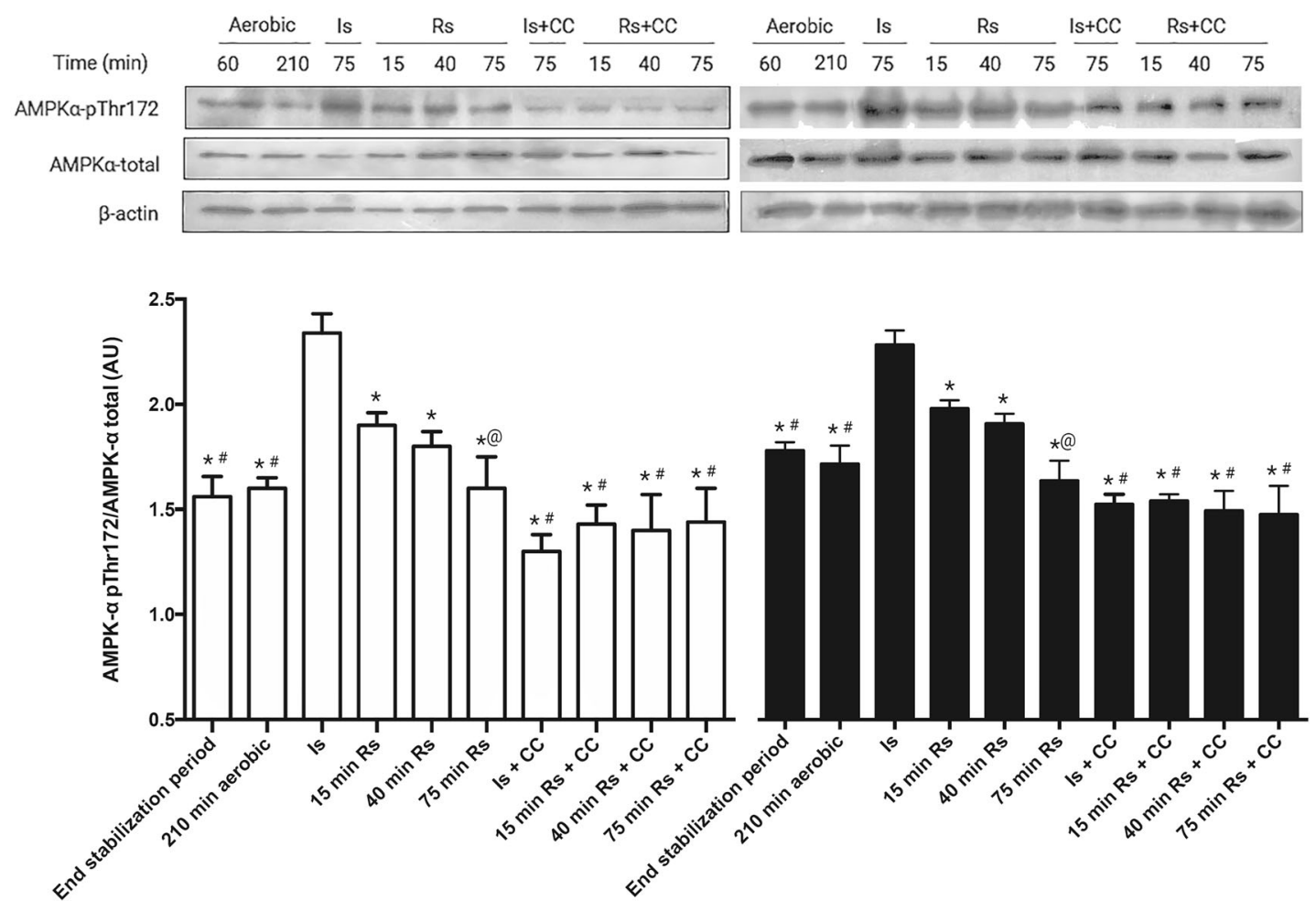

\section{$10 \mathrm{mM}$ Glucose}

$10 \mathrm{mM}$ Glucose + $1.2 \mathrm{mM}$ palmitate

Fig. 1 Western blot Immunoblot composite images, showing phosphorylated $\alpha$-subunit in $\operatorname{Thr}^{172}$ (AMPK $\alpha$-pThr ${ }^{172}$ ) and total enzyme $\alpha$-subunit (AMPK $\alpha$-total) expression in rat atria a subjected to $15-, 40-$, and 75-min simulated ischemia and b subjected to 15-, 40-, and 75-min simulated reperfusion. Immunoblot bands were normalized to corresponding $\beta$-actin. The values for the AMPK $\alpha-p T^{172}$ and AMPK- $\alpha$ total ratio are mean $\pm \operatorname{SEM}(n=5 /$ each condition). $C C, 10 \mu \mathrm{M}$ compound C. ${ }^{\otimes} p<0.05$ vs 15,40 , and $75 \mathrm{~min}$ Is in both metabolic conditions; ${ }^{\Phi} p<0.05$ vs 40 and 75 min Is in both metabolic conditions; ${ }^{*} p<0.05$ vs Is in both metabolic conditions; ${ }^{\#} p<0.05$ vs 15 and 40 min Rs in both metabolic conditions; ${ }^{\circledR} p<0.05$ vs $15 \mathrm{~min}$ Rs in both metabolic conditions 
a
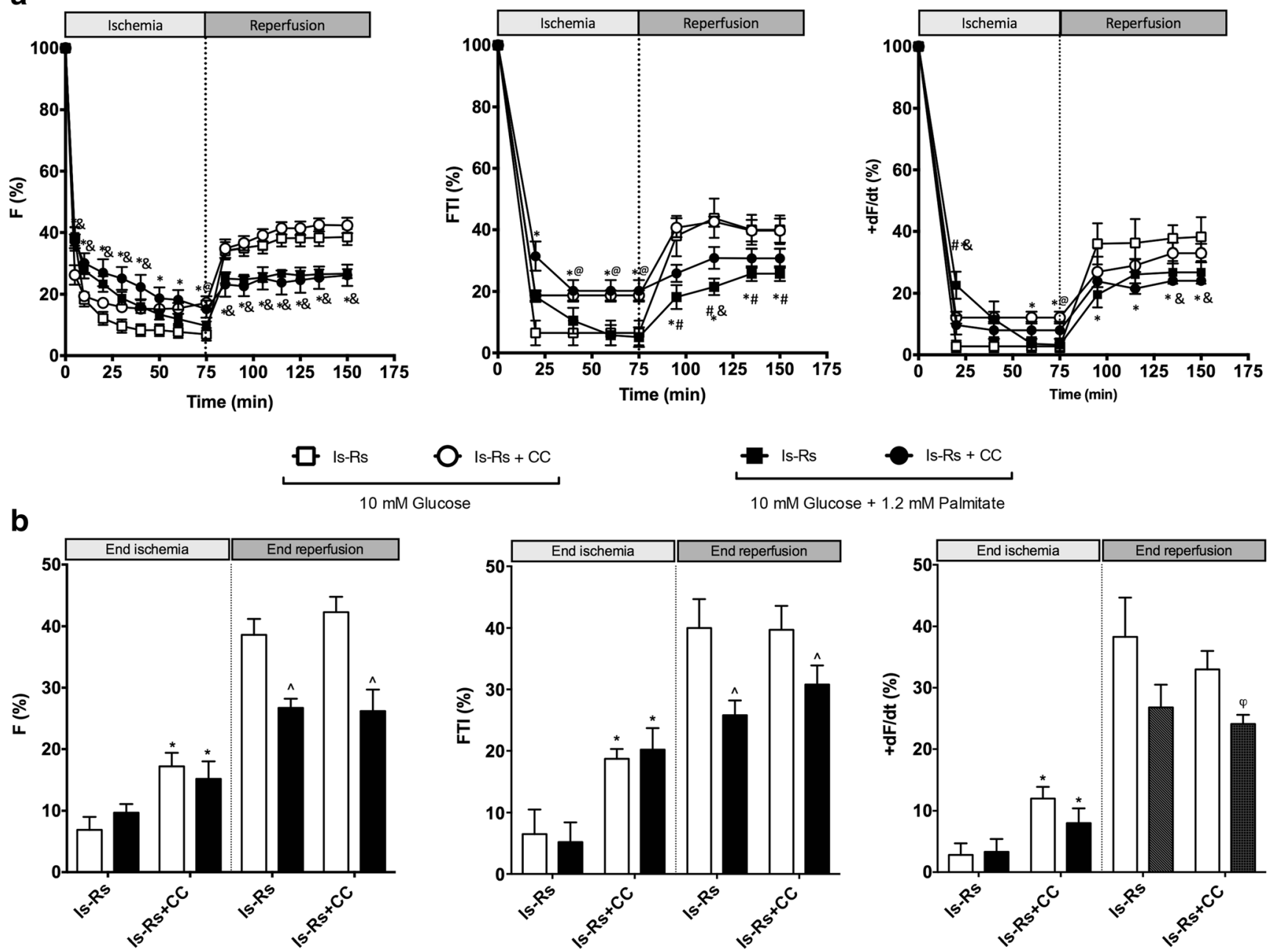

$10 \mathrm{mM}$ Glucose

Fig. 2 Atrial systolic function. Effects of $10 \mu \mathrm{M}$ compound $\mathrm{C}(\mathrm{CC})$ on peak developed force $(F)$, peak rate of contraction $(+\mathrm{d} F / \mathrm{d} t)$ and forcetime index (FTI) in left isolated rat atria subjected to simulated ischemia reperfusion in the presence of $10 \mathrm{mM}$ glucose or $10 \mathrm{mM}$ glucose and $1.2 \mathrm{mM}$ palmitate exogenous substrates. Values (mean $\pm \mathrm{SEM}, n=8 /$ each condition) are expressed as a percentage of the respective basal values at the end of the 60-min stabilization period. a Effects of compound $\mathrm{C}$ on atrial contractile function during $75 \mathrm{~min}$ of simulated ischemia and 75 min reperfusion. $* p<0.05$ vs Is-Rs in the presence of $10 \mathrm{mM}$ glucose as sole exogenous substrate; ${ }^{*} p<0.05$ vs Is-Rs + CC in the presence of $10 \mathrm{mM}$ glucose and $1.2 \mathrm{mM}$ palmitate as exogenous substrates; ${ }^{*} p<0.05$

pronounced reduction in lactate accumulation during the ischemic period, showing no significant differences between both groups (Fig. 5).

\section{Tissue ATP content}

To assess whether the differences observed between groups in peak ischemic contracture development were accompanied with differences in ATP levels, tissue ATP content was determined at 20-min Is. Figure 6 shows that ATP levels fell to
$10 \mathrm{mM}$ Glucose + $1.2 \mathrm{mM}$ Palmitate

vs Is-Rs $+\mathrm{CC}$ in the presence of $10 \mathrm{mM}$ glucose as sole exogenous substrate; ${ }^{\circledR} p<0.05$ vs Is-Rs in the presence of $10 \mathrm{mM}$ glucose and $1.2 \mathrm{mM}$ palmitate as exogenous substrates. b Effects of compound C on atrial contractile function at the end of simulated ischemia and reperfusion. ${ }^{*} p<0.05$ vs Is-Rs in the presence of $10 \mathrm{mM}$ glucose as sole exogenous substrate and Is-Rs in the presence of $\mathrm{CC}$ in the presence of $10 \mathrm{mM}$ glucose and $1.2 \mathrm{mM}$ palmitate as exogenous substrates; ${ }^{\wedge} p<0.05$ vs Is-Rs in the presence of $10 \mathrm{mM}$ glucose as sole exogenous substrate and Is-Rs $+\mathrm{CC}$ in the presence of $10 \mathrm{mM}$ glucose as sole exogenous substrates; ${ }^{\varphi} p<0.05$ vs all end reperfusion groups

lower values when atria were incubated with $10 \mathrm{mM}$ glucose and $1.2 \mathrm{mM}$ palmitate. Moreover, when the intrinsic AMPK activation was inhibited, the atria stabilized in the presence of glucose and palmitate contained substantially less ATP than all other groups. However, in atria stabilized with glucose as sole exogenous substrate, inhibition of AMPK did not affect ATP content, which was similar to control atria. At the end of 75-min Is, tissue ATP levels fell to even lower values, being this reduction more pronounced by the presence of palmitate as exogenous substrate. Compound C reduced ATP content 
a

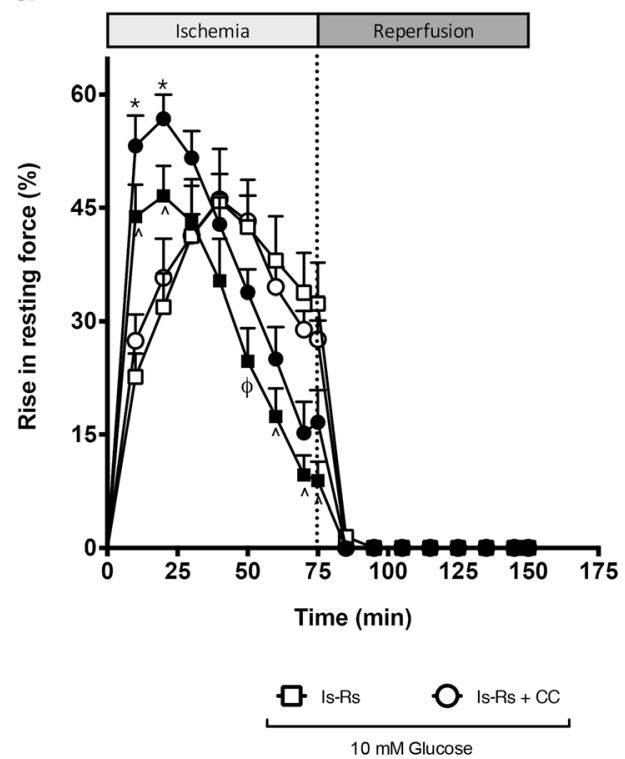

b

\begin{tabular}{|c|c|cc|}
\hline \multicolumn{3}{|c|}{ Maximum ischemic contracture } \\
\cline { 2 - 4 } & & $\begin{array}{c}\text { Rise in resting } \\
\text { force }(\%)\end{array}$ & Time of ischemia \\
\hline \multirow{2}{*}{$10 \mathrm{mM}$ Glucose } & Is-Rs & $45.8 \pm 5.0$ & $40 \mathrm{~min}$ \\
& Is-Rs + CC & $46.1 \pm 3.4$ & $40 \mathrm{~min}$ \\
\hline $10 \mathrm{mM}$ Glucose + & Is-Rs & $46.5 \pm 3.8$ & $20 \mathrm{~min}^{*}$ \\
$1.2 \mathrm{mM}$ Palmitate & Is-Rs + CC & $56.8 \pm 3.2^{*}$ & $20 \mathrm{~min}^{*}$ \\
\hline
\end{tabular}

Fig. 3 Atrial diastolic function. a Effects of $10 \mu \mathrm{M}$ compound $\mathrm{C}$ (CC) on resting force and peak rate of relaxation $(-\mathrm{d} F / \mathrm{d} t)$ in isolated left atria subjected to $75 \mathrm{~min}$ simulated ischemia-75 min reperfusion (Is-Rs) in the presence of $10 \mathrm{mM}$ glucose or $10 \mathrm{mM}$ glucose and $1.2 \mathrm{mM}$ palmitate exogenous substrates. All values are expressed as mean $\pm \operatorname{SEM}(n=8 /$ each condition). Rise in resting force is expressed as a percentage of the peak force developed at the end of the stabilization period and $-\mathrm{d} F / \mathrm{d} t$ as a percentage of the respective basal value at the end of the stabilization period. $* p<0.05$ vs Is-Rs in both metabolic conditions and Is-Rs + CC in the presence of $10 \mathrm{mM}$ glucose as sole exogenous substrate; ${ }^{\#} p<0.05$ vs Is-Rs in the presence of $10 \mathrm{mM}$ glucose as sole exogenous substrate; ${ }^{\circledR} p<0.05$ vs Is-Rs in both metabolic conditions; ${ }^{\wedge} p<0.05$ vs Is-Rs in the presence of $10 \mathrm{mM}$ glucose as sole exogenous substrate and Is-Rs $+\mathrm{CC}$ in the presence of $10 \mathrm{mM}$ glucose as sole exogenous substrate; ${ }^{\wedge} p<0.01$ vs Is-Rs in the presence of $10 \mathrm{mM}$ glucose as sole exogenous substrate and Is-Rs $+\mathrm{CC}$ in the presence of $10 \mathrm{mM}$ glucose as sole exogenous substrate; ${ }^{\&} p<0.05$ vs Is-Rs $+C C$ in the presence of $10 \mathrm{mM}$ glucose as sole exogenous substrate; ${ }^{\varphi} p<0.05$ vs Is-Rs $+\mathrm{CC}$ in the presence of $10 \mathrm{mM}$ glucose and $1.2 \mathrm{mM}$ palmitate as exogenous substrates; ${ }^{\phi} p<0.05$ vs Is-Rs in the presence of $10 \mathrm{mM}$ glucose as sole exogenous substrate and Is-Rs $+\mathrm{CC}$ in both metabolic conditions. $\mathbf{b}$ Effects of compound $\mathrm{C}$ on

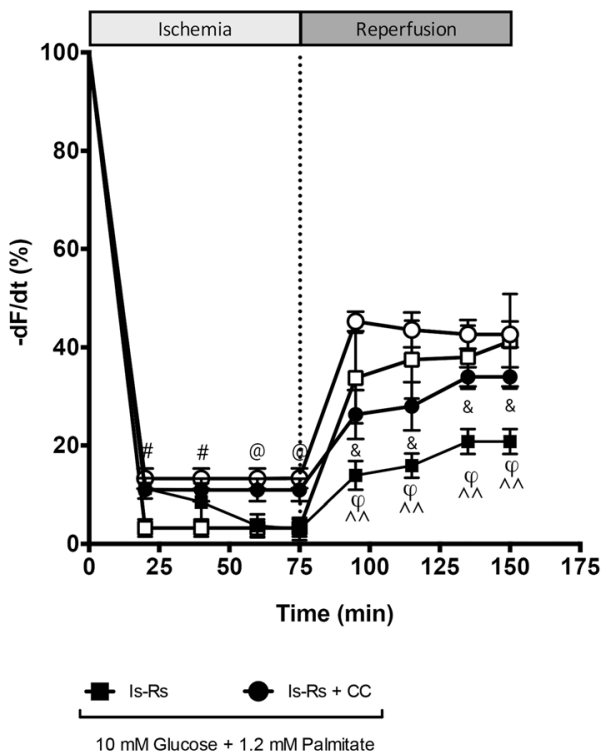

C

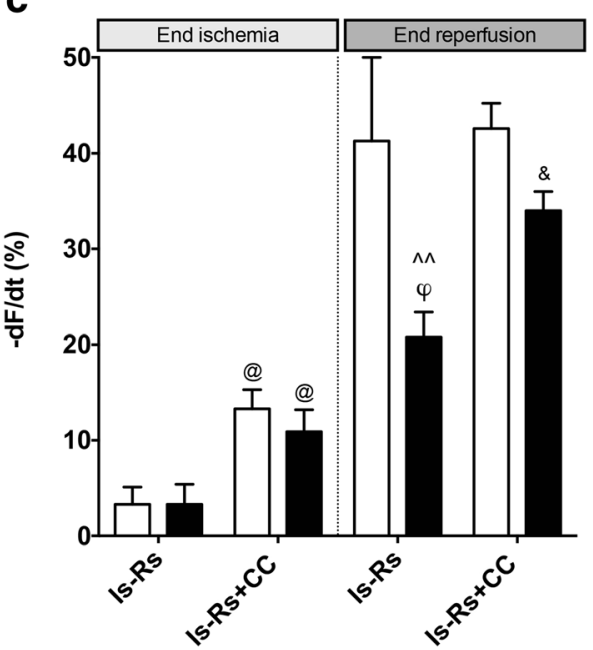

maximum ischemic contracture. Data shows rise in resting force, expressed as a percentage of the peak force developed at the end of the stabilization period, when maximum ischemic contracture was developed in isolated left atria subjected to simulated ischemia in the presence of $10 \mathrm{mM}$ glucose or $10 \mathrm{mM}$ glucose and $1.2 \mathrm{mM}$ palmitate exogenous substrates. The time of ischemia maximum ischemic contracture was developed is also shown. All values (mean $\pm \mathrm{SEM}, n=8$ /each condition). $* p<0.05$ vs Is-Rs in both metabolic conditions and Is-Rs $+\mathrm{CC}$ in the presence of $10 \mathrm{mM}$ glucose as sole exogenous substrate; ${ }^{*} p<0.05$ vs IsRs in the presence of $10 \mathrm{mM}$ glucose as sole exogenous substrate and Is$\mathrm{Rs}+\mathrm{CC}$ in the presence of $10 \mathrm{mM}$ glucose as sole exogenous substrate. $\mathrm{c}$ Effects of compound $\mathrm{C}$ on atrial maximum peak of relaxation at the end of simulated ischemia and reperfusion. All values are expressed as mean $\pm \operatorname{SEM}(n=8 /$ each condition). $-\mathrm{d} F / \mathrm{d} t$ is expressed as a percentage of the respective basal value at the end of the stabilization period; ${ }^{\circledR} p<0.05$ vs Is-Rs in both metabolic conditions; ${ }^{\wedge} p<0.01$ vs Is-Rs in the presence of $10 \mathrm{mM}$ glucose as sole exogenous substrate and Is-Rs + $\mathrm{CC}$ in the presence of $10 \mathrm{mM}$ glucose as sole exogenous substrate; ${ }_{p}<0.05$ vs Is-Rs $+\mathrm{CC}$ in the presence of $10 \mathrm{mM}$ glucose as sole exogenous substrate; ${ }^{\varphi} p<0.05$ vs Is-Rs $+\mathrm{CC}$ in the presence of $10 \mathrm{mM}$ glucose and $1.2 \mathrm{mM}$ palmitate as exogenous substrates 
$10 \mathrm{mM}$ Glucose
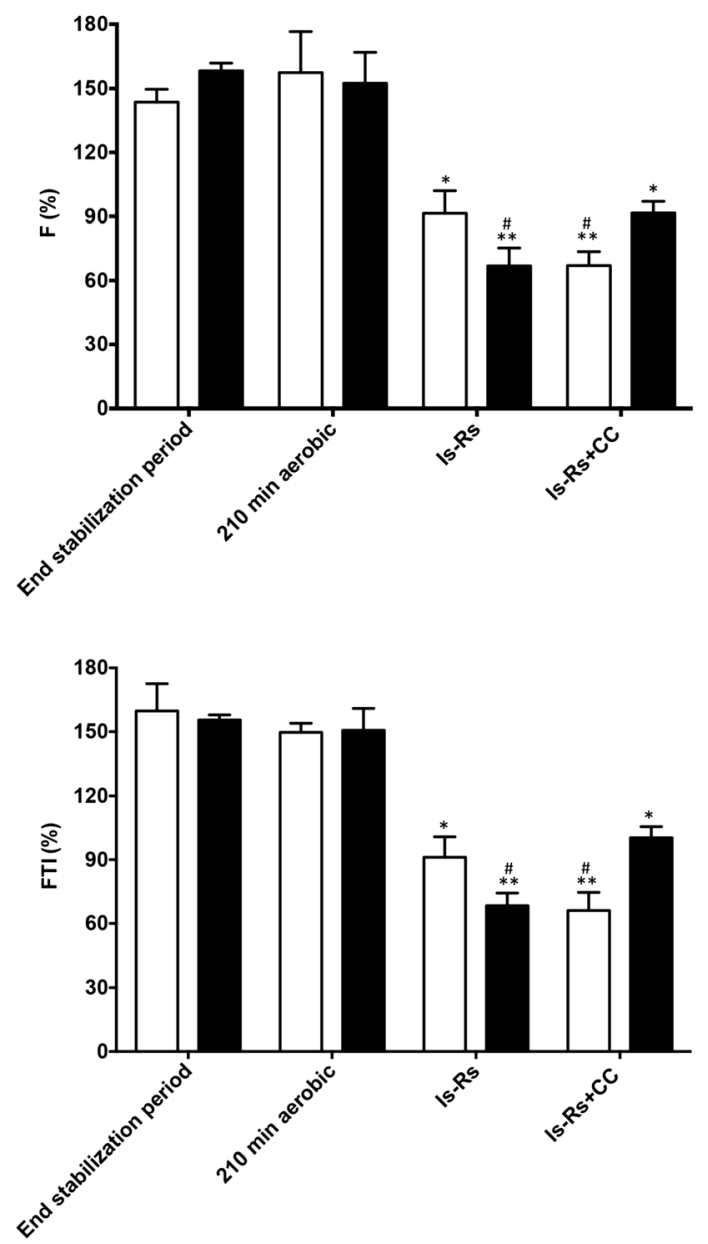

Fig. 4 Contractile reserve. Effects of $10 \mu \mathrm{M}$ compound $\mathrm{C}$ (CC) on the maximal inotropic response to a $\beta$-adrenergic agent $(2 \mu \mathrm{M}$ isoproterenol) in isolated left atria subjected to simulated ischemia-reperfusion in the presence of $10 \mathrm{mM}$ glucose or $10 \mathrm{mM}$ glucose and $1.2 \mathrm{mM}$ palmitate exogenous substrates. For this aim peak developed force $(F)$, force-time index $(\mathrm{FTI})$, peak rate of contraction $(+\mathrm{d} F / \mathrm{d} t)$, and peak rate of relaxation $(-\mathrm{d} F / \mathrm{d} t)$ was assessed. All values (mean $\pm \mathrm{SEM}, n=8$ /each condition)

even more when atria were incubated with glucose as sole exogenous substrate; however, it did not affect tissue ATP levels in the presence of palmitate.

Figure 6 also shows that changes in contractile recovery were accompanied by similar changes in tissue ATP content. The results also demonstrate that the effects observed in the presence of oxfenicine were accompanied by similar levels of tissue ATP content observed in the presence of compound $\mathrm{C}$ in each metabolic condition.

\section{Pyruvate dehydrogenase activity}

The mitochondrial oxidative decarboxylation of pyruvate to acetyl-CoA and $\mathrm{CO}_{2}$ is catalyzed by the multienzyme pyruvate dehydrogenase (PDH) complex. The enzyme complex
$10 \mathrm{mM}$ Glucose + $1.2 \mathrm{mM}$ Palmitate
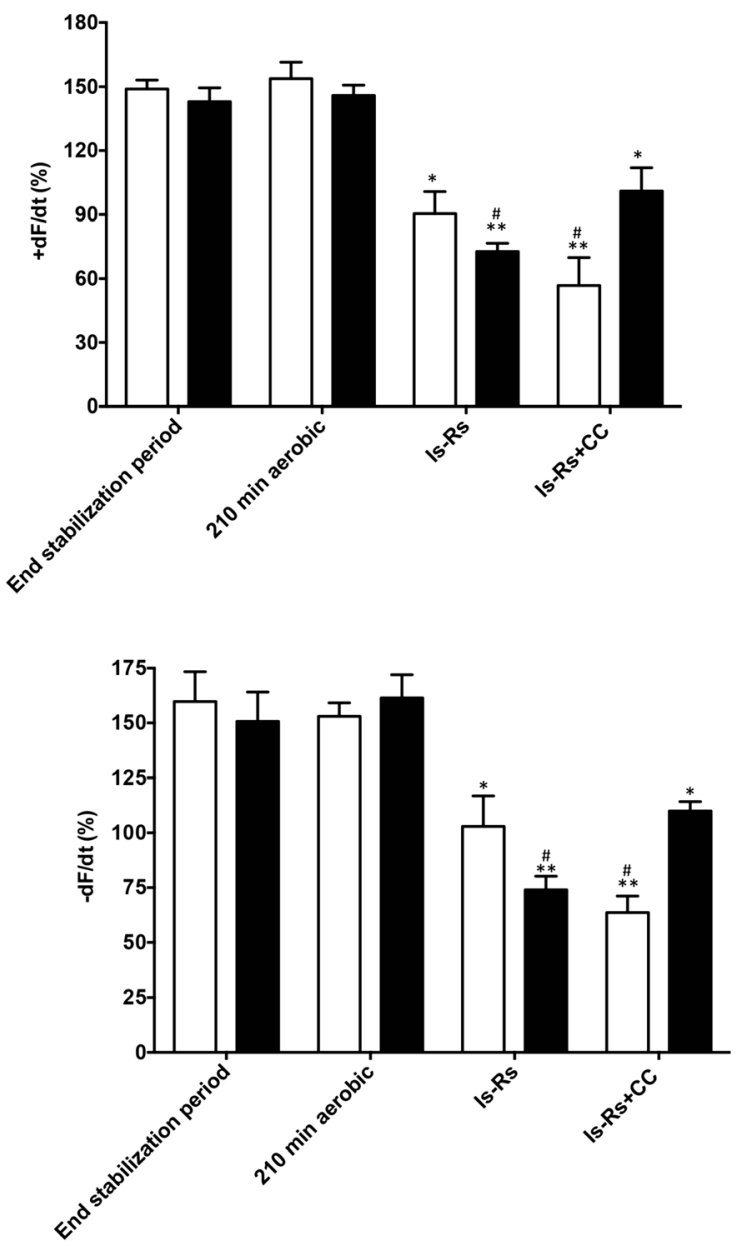

were recorded $30 \mathrm{~min}$ after the addition of $2 \mu \mathrm{M}$ isoproterenol (ISO), at this time atria of all groups reached maximal inotropic response and are expressed as a percentage of the respective basal value at the end of the 60 -min stabilization period. $* * p<0.01$ vs end stabilization period and 210 min aerobic in both metabolic conditions; $* p<0.05$ vs end stabilization period and $210 \mathrm{~min}$ aerobic in both metabolic conditions; ${ }^{\#} p<0.05$ vs Is-Rs in both metabolic conditions

plays an important role in the regulation of glucose oxidation, determining whether the mitochondria metabolize glucose or lipid fuels for ATP generation. In this study, the PDH activity was assessed to determine if the effects observed in the presence of palmitate were accompanied by PDH inhibition through Randle cycle effect.

Results showed that PDH activity after 75-min simulated ischemia increased $37 \%$ in the atria incubated in the presence of $10 \mathrm{mM}$ glucose as sole exogenous substrate. The activity of the enzyme remained elevated after 75-min reperfusion. However, in the atria subjected to Is-Rs in the presence of glucose and palmitate, Fig. 7 shows that PDH activity was significantly reduced. On the other hand, when intrinsic AMPK activation was inhibited by compound $\mathrm{C}$, the effects of palmitate on PDH activity were partially reverted, 
Exogenous substrates present in the experiments performed

\begin{tabular}{|c|c|c|c|c|c|c|c|}
\hline & \multirow{2}{*}{\multicolumn{3}{|c|}{$10 \mathrm{mM}$ Glucose }} & & & \\
\hline & & & & & \multicolumn{3}{|c|}{$10 \mathrm{mM}$ glucose $+1.2 \mathrm{mM}$ palmitate } \\
\hline & & Is-Rs & Is-Rs $+\mathrm{CC}$ & Is-Rs + Oxf & Is-Rs & Is-Rs $+\mathrm{CC}$ & Is-Rs + Oxf \\
\hline \multirow[t]{4}{*}{ Maximal inotropic response ( $2 \mathrm{pM}$ ISO) } & $F$ & $91.4 \pm 10.56$ & $67.0 \pm 6.6^{\#}$ & $69.1 \pm 6.1^{\#}$ & $66.9 \pm 8.4^{\#}$ & $91.6 \pm 5.4$ & $94.3 \pm 10.3$ \\
\hline & $+\mathrm{d} F / \mathrm{d} t$ & $90.4 \pm 10.3$ & $56.8 \pm 13.1^{\#}$ & $67.9 \pm 1.1^{\#}$ & $72.7 \pm 3.9^{\#}$ & $102.0 \pm 11.0$ & $89.2 \pm 10.7$ \\
\hline & FTI & $91.1 \pm 9.6$ & $66.1 \pm 8.5^{\#}$ & $63.2 \pm 7.5^{\#}$ & $68.3 \pm 6.0^{\#}$ & $100.3 \pm 5.3$ & $90.3 \pm 6.5$ \\
\hline & $-\mathrm{d} F / \mathrm{d} t$ & $103.0 \pm 13.9$ & $63.6 \pm 7.6^{\#}$ & $60.8 \pm 7.6^{\#}$ & $74.0 \pm 6.2^{\#}$ & $110.0 \pm 4.3$ & $100.1 \pm 7.7$ \\
\hline
\end{tabular}

Effects of oxfenicine on the maximal inotropic response to $2 \mu \mathrm{M}$ isoproterenol (ISO) in isolated left atria subjected to simulated ischemia-reperfusion in the presence of $10 \mathrm{mM}$ glucose or $10 \mathrm{mM}$ glucose and $1.2 \mathrm{mM}$ palmitate exogenous substrates. For this aim, peak developed force $(F)$, force-time index (FTI), peak rate of contraction $(+\mathrm{d} F / \mathrm{d} t)$, and peak rate of relaxation $(-\mathrm{d} F / \mathrm{d} t)$ was assessed. All values (mean \pm SEM, $n=6-8 /$ each condition) were recorded $30 \mathrm{~min}$ after addition of ISO and are expressed as a percentage of the respective basal value at the end of the 60-min stabilization period

$\mathrm{CC}, 10 \mu \mathrm{M}$ compound $\mathrm{C}$

${ }^{\#} p<0.05$ vs Is-Rs in the presence of $10 \mathrm{mM}$ glucose as sole exogenous substrate, Is-Rs $+\mathrm{CC}$ in the presence of $10 \mathrm{mM}$ glucose and $1.2 \mathrm{mM}$ palmitate as exogenous substrate, and Is-Rs $+\mathrm{Oxf}+\mathrm{CC}$ in the presence of $10 \mathrm{mM}$ glucose and $1.2 \mathrm{mM}$ palmitate as exogenous substrate

increasing the enzyme activity $18 \%$ compared with aerobic control. Conversely, when atria were incubated in the presence of glucose as sole exogenous substrate, compound $\mathrm{C}$ reduced PDH activity (Fig. 7).

\section{Cellular viability}

Atria subjected to a 60 -min aerobic stabilization period were considered $100 \%$ viable cells. Cell viability was not affected by 210-min of aerobic conditions or Is, either in the presence of glucose as sole exogenous substrate or glucose and palmitate (Fig. 8). After 75-min reperfusion, the percentage

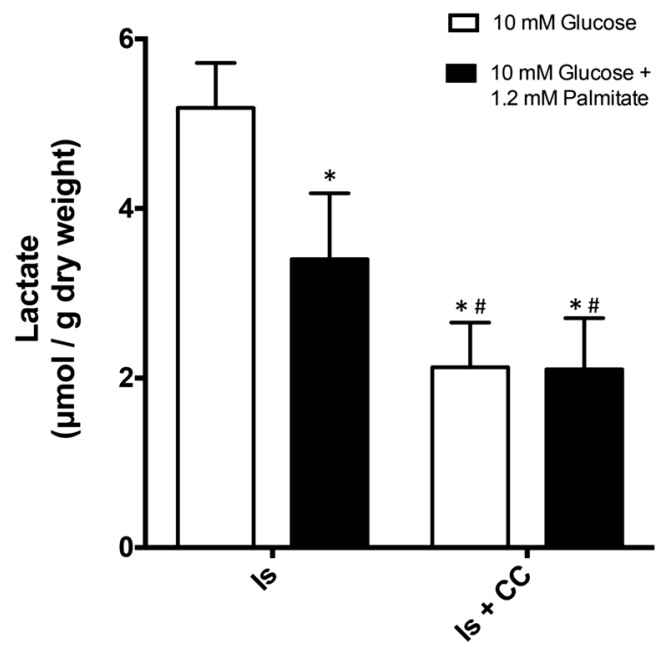

Fig. 5 Lactate tissue content. Effects of $10 \mu \mathrm{M}$ compound C (CC) on lactate tissue content in isolated left atria subjected to simulated ischemia in the presence of $10 \mathrm{mM}$ glucose or $10 \mathrm{mM}$ glucose and $1.2 \mathrm{mM}$ palmitate exogenous substrates during 60 -min aerobic stabilization period. Values are mean $\pm \operatorname{SEM}(n=8 /$ each condition) and are expressed as $\mu \mathrm{mol} / \mathrm{g}$ dry weight. $* p<0.05$ vs Is in the presence of $10 \mathrm{mM}$ glucose as sole exogenous substrate; ${ }^{\#} p<0.05$ vs Is in the presence of $10 \mathrm{mM}$ glucose and $1.2 \mathrm{mM}$ palmitate as exogenous substrates of viable myocytes was reduced reaching similar values in both metabolic conditions. Compound $\mathrm{C}$ did not affect cellular viability percentage after reperfusion period, showing no significant differences between treated and non-treated groups (Fig. 8).

\section{Discussion}

In the present study, we investigated the role of intrinsic AMPK activation in the response to simulated ischemia-reperfusion in isolated rat left atria. For this purpose, the wellstudied inhibitor of AMPK, compound $\mathrm{C}$, was added to the bathing medium at the onset of simulated ischemia and maintained throughout the experiment $[6,31]$. Since in most clinical situations of ischemia-reperfusion the heart muscle is exposed to high levels of fatty acids within the first $30 \mathrm{~min}$ from the appearance of symptoms associated with the development of acute myocardial infarction, which would be due to an increase in catecholamine discharge along with the plasma increase of glucocorticoids, the influence of palmitate present in the incubation medium was also investigated [12, 38, 46, $53,56]$. For this aim, atria subjected to Is-Rs were incubated in two different metabolic conditions, containing the bathing medium $10 \mathrm{mM}$ D-glucose as sole exogenous substrate or $10 \mathrm{mM}$ D-glucose and $1.2 \mathrm{mM}$ palmitate pre-bound to $3 \%$ bovine serum albumin. The results of this study showed that AMPK is activated during Is, remaining activated during Rs. During Is, peak contracture developed earlier in the atria stabilized with palmitate. In this condition, AMPK inhibition also increased maximum contracture developed. These results were consistent with parallel changes in tissue ATP content. At the end of Rs contractile function recovery was reduced by palmitate but not by AMPK inhibition. However, AMPK 


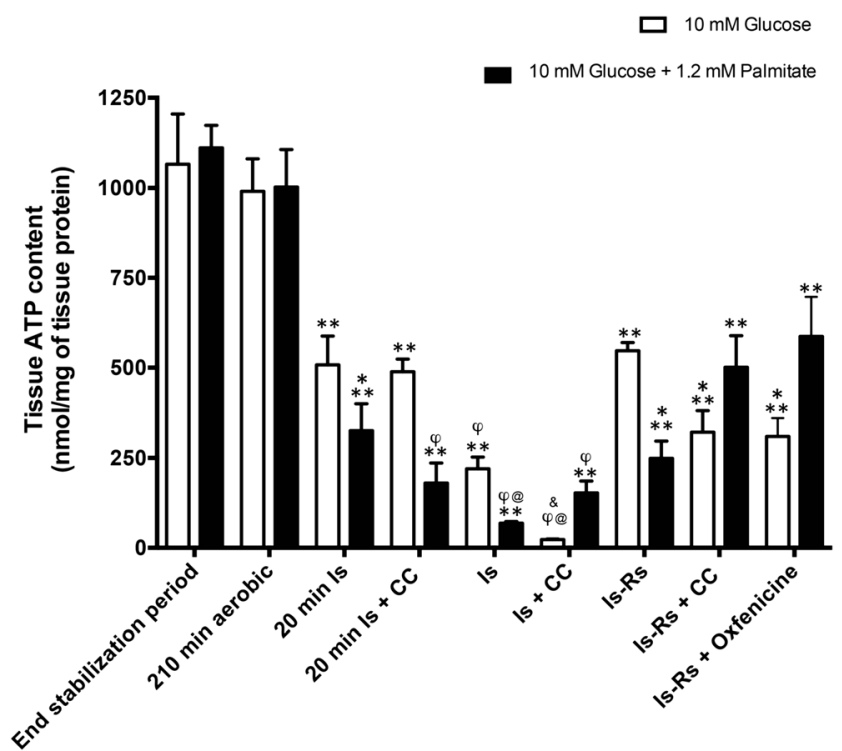

Fig. 6 Tissue ATP content. Effects of $10 \mu \mathrm{M}$ compound C (CC) on tissue ATP content in isolated left atria subjected to simulated ischemia in the presence of $10 \mathrm{mM}$ glucose or $10 \mathrm{mM}$ glucose and $1.2 \mathrm{mM}$ palmitate exogenous substrates. Values are mean $\pm \operatorname{SEM}(n=8 /$ each condition $)$ and are expressed as $\mathrm{pmol} / \mathrm{mg}$ tissue protein $* * p<0.05$ vs end stabilization period and $210 \mathrm{~min}$ aerobic in both metabolic conditions; ${ }^{*} p<0.05$ vs $20 \mathrm{~min}$ Is in the presence of $10 \mathrm{mM}$ glucose as sole exogenous substrate and $20 \mathrm{~min}$ Is $+\mathrm{CC}$ in the presence of $10 \mathrm{mM}$ glucose as sole exogenous substrate, Is-Rs in the presence of $10 \mathrm{mM}$ glucose as sole exogenous substrate, and Is-Rs + CC in the presence of $10 \mathrm{mM}$ glucose and $1.2 \mathrm{mM}$ palmitate as exogenous substrates; ${ }^{\varphi} p<0.05$ vs $20 \mathrm{~min}$ Is in the presence of $10 \mathrm{mM}$ glucose as sole exogenous substrate, $20 \mathrm{~min}$ Is + $\mathrm{CC}$ in the presence of $10 \mathrm{mM}$ glucose as sole exogenous substrate, and $20 \mathrm{~min}$ Is in the presence of $10 \mathrm{mM}$ glucose and $1.2 \mathrm{mM}$ palmitate as exogenous substrates, Is-Rs in the presence of $10 \mathrm{mM}$ glucose as sole exogenous substrate, and Is-Rs $+\mathrm{CC}$ in the presence of $10 \mathrm{mM}$ glucose and $1.2 \mathrm{mM}$ palmitate as exogenous substrates; ${ }^{\circledR} \mathrm{P}<0.05$ vs $20 \mathrm{~min}$ Is + $\mathrm{CC}$ in the presence of $10 \mathrm{mM}$ glucose and $1.2 \mathrm{mM}$ palmitate as exogenous substrates, Is in the presence of $10 \mathrm{mM}$ glucose as sole exogenous substrate, and Is + CC in the presence of $10 \mathrm{mM}$ glucose and $1.2 \mathrm{mM}$ palmitate as exogenous substrates; ${ }^{\&} p<0.05$ vs all other groups

inhibition showed dual effect on contractile reserve, it increased this functional parameter attenuation in the presence of glucose but reversed the harmful effect of palmitate. These results were accompanied by parallel changes in tissue ATP content, although the rate of mitochondrial ATP synthesis was not affected. However, AMPK inhibition showed dual effect on PDH activity, decreasing its activity in the atria incubated with glucose, but partially reverting the decrease in PDH activity induced by palmitate. Cellular viability was not affected by palmitate or AMPK inhibition. These results support that intrinsic activation of AMPK has functional protective effects in the reperfused atria when glucose is the only available energetic substrate whereas it is deleterious when palmitate is also available.

The present data shows that AMPK phosphorylation at $\mathrm{Thr}^{172}$ increased during simulated ischemia, demonstrating that AMPK activation occurs during myocardial ischemia and persists at least during 40-min reperfusion. On the other

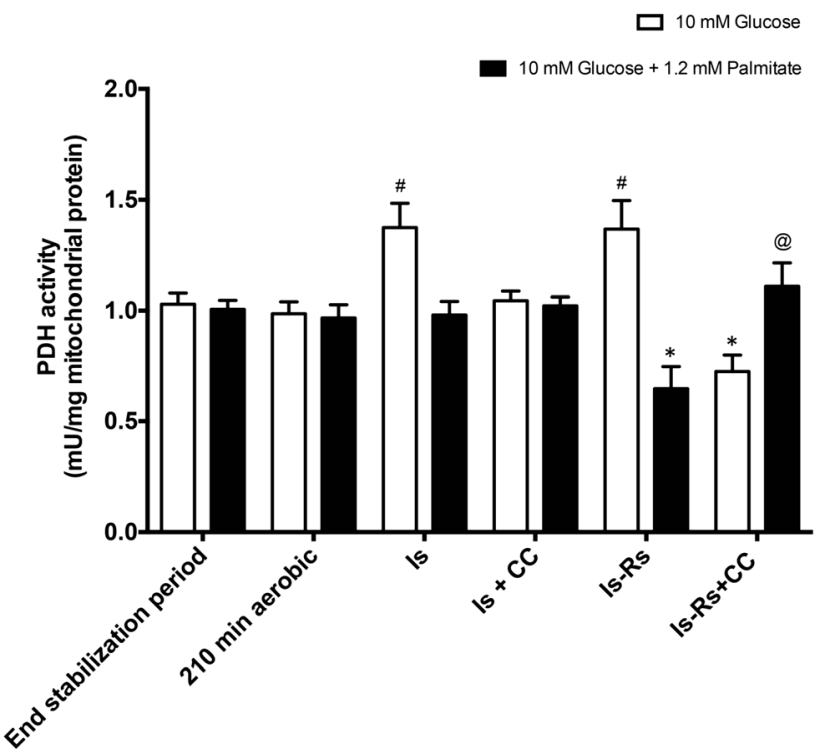

Fig. 7 Pyruvate dehydrogenase activity. Effects of $10 \mu \mathrm{M}$ compound $\mathrm{C}$ (CC) on PDH activity in isolated left atria subjected to simulated ischemia in the presence of $10 \mathrm{mM}$ glucose or $10 \mathrm{mM}$ glucose and $1.2 \mathrm{mM}$ palmitate exogenous substrates. Values are mean $\pm \operatorname{SEM}(n=8 /$ each condition) and are expressed as milliunits per microgram of mitochondrial protein. ${ }^{*} p<0.05$ vs all groups; ${ }^{*} p<0.05$ vs end stabilization period aerobic in both metabolic conditions, $210 \mathrm{~min}$ aerobic in both metabolic conditions, Is in the presence of $10 \mathrm{mM}$ glucose and $1.2 \mathrm{mM}$ palmitate as exogenous substrates, and Is + CC in both metabolic conditions, Is-Rs+CC in the presence of $10 \mathrm{mM}$ glucose and $1.2 \mathrm{mM}$ palmitate as exogenous substrates; ${ }^{@} p<0.05$ vs Is in the presence of $10 \mathrm{mM}$ glucose, Is-Rs in both metabolic conditions, Is-Rs+CC in the presence of glucose $10 \mathrm{mM}$

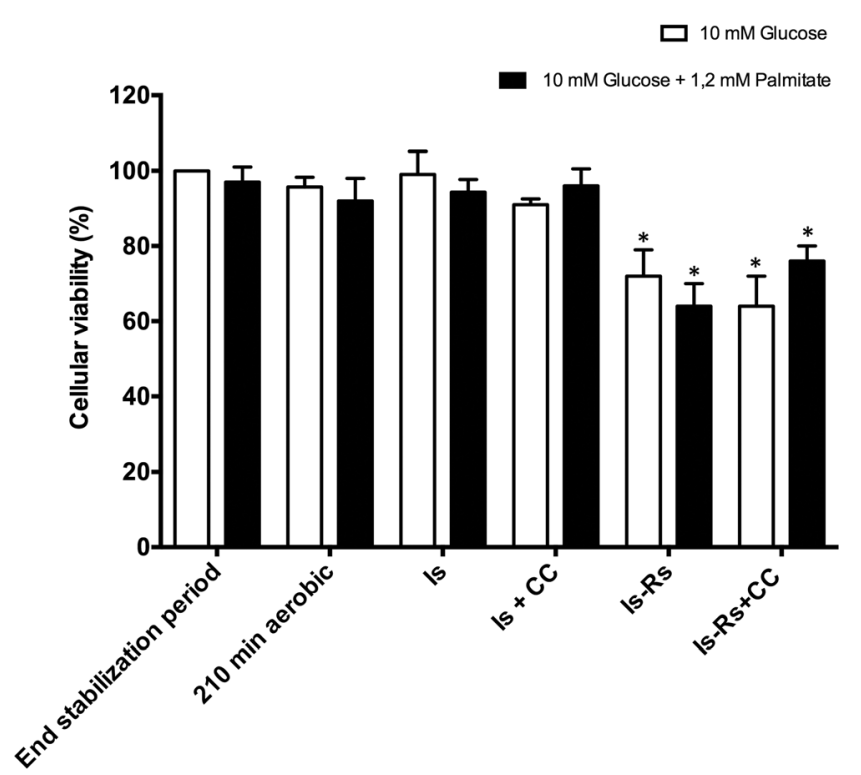

Fig. 8 Cellular viability. Effects of $10 \mu \mathrm{M}$ compound C (CC) on cellular viability, in isolated left atria subjected to simulated ischemia in the presence of $10 \mathrm{mM}$ glucose or $10 \mathrm{mM}$ glucose and $1.2 \mathrm{mM}$ palmitate exogenous substrates. Atria subjected to the 60 -min aerobic stabilization period were considered $100 \%$ viable cells. Values are mean $\pm \operatorname{SEM}(n=8 /$ each condition) and are expressed as percentage of the pre-ischaemic value. $* p<0.05$ vs end stabilization period, $210 \mathrm{~min}$ aerobic, Is, and Is $+\mathrm{CC}$, all in both metabolic conditions 
hand, compound $\mathrm{C}$ was able to inhibit AMPK activation. These results are consistent with the findings reported by other authors, who demonstrated that in Langendorff perfused rat hearts subjected to 30-min period of global no-flow ischemia and a subsequent 60 -min period of aerobic reperfusion, AMPK activity was significantly elevated in both the ischemic and reperfused ischemic hearts, compared with those aerobically perfused $[4,36]$. Kudo et al. proposed that the activation of AMPK during the ischemic period occurs secondary to the increase in 5'-AMP, either due to a direct activation of AMPK or secondary to phosphorylation of AMPK by AMPK upstream kinase. The authors also state that during reperfusion the activity of AMPK remains elevated, even though 5'-AMP levels return to pre-ischemic values [21].

The lack of oxygen during myocardial ischemia determines an immediate blocking of oxidative phosphorylation, with failure of aerobic ATP synthesis and accumulation of oxidative phosphorylation substrates. However, in this condition anaerobic glycolysis remains active. In this process, glucose is formed by endogenous glycogen stores and catabolized to pyruvate, which is in turn converted to lactate by lactate dehydrogenase, yielding $2 \mathrm{~mol}$ of ATP/mol of glucose [32, 79]. On the other hand, it is well known that extracellular levels of fatty acids are an important determinant of myocardial substrate use; in 1960s, Randle et al. discovered that high levels of fatty acids decrease glucose utilization under well oxygenated conditions (Randle effect) [19]. Considering that in most clinical situations of ischemia-reperfusion the myocardium is exposed to high levels of fatty acids, the present results suggest that after aerobic incubation in the presence of $1.2 \mathrm{mM}$ palmitate, the Randle effect continues to function during simulated ischemia, since the anaerobic glycolysis, estimated from lactate accumulation, was reduced. Moreover, peak ischemic contracture occurred much more rapidly, shifting from 40- to 20 -min reperfusion. To this respect, it has been shown by Hearse et al. that ischemic contracture is closely related to tissue ATP content [27]. It has been shown that the gradual decrease in the concentration of tissue ATP, below a critical concentration, contributes to the development of ischemic contracture $[1,54]$. In this regard, the main cause related to the development of contracture, although not the only one, would be the formation of stable junctions or "rigor" actinmyosin junctions, which require ATP to dissociate [61]. This type of contracture is reversible, usually moderate and, although it does not generate great structural damage, produces alterations in the cytoskeleton that make myocytes more susceptible to mechanical damage [61]. At the time peak ischemic contracture occurred in atria incubated with glucose and palmitate, ATP levels fell to lower values than in atria incubated with glucose as sole exogenous substrate. To this respect, it has been reported that during ischemia AMPK has a dual role, increasing both glycolysis and fatty acid oxidation to increase overall energy production in response to high energy demand [17, 42]. Our results show that when the intrinsic AMPK activation was inhibited, the atria stabilized in the presence of palmitate exhibited enhanced peak ischemic contracture and contained substantially less ATP than all other groups. However, in atria stabilized with glucose as sole exogenous substrate, inhibition of AMPK did not affect contracture and ATP content was similar to control atria after 20-min ischemia. Present data suggests that the quantity of ATP depletion may be responsible for peak contracture and time to peak contracture [33], probably producing rigor bonds, although other variables involving cytosolic calcium levels and intracellular $\mathrm{pH}$ may contribute to contracture in this experimental model. Lactate accumulation during ischemia suggests that anaerobic glycolysis, major source of ATP during ischemia, is partly stimulated by AMPK; however, it is not possible to associate changes in contracture with lactate accumulation. In the study by Xing et al. [85], isolated ischemicreperfused hearts from transgenic mice with cardiac-specific overexpression of a dominant negative mutant of the AMPK $\alpha_{2}$ catalytic subunit exhibited exacerbated ATP depletion during ischemia and enhanced left ventricular end-diastolic pressure that could not be attributed to impaired glycolytic ATP synthesis. Since it is well known that fatty acid utilization is stimulated by AMPK, utilization of glucose may be affected by more complex ways in the presence of compound $\mathrm{C}$ than in its absence.

On the other hand, the presence of high levels of palmitate resulted in a smaller post-ischemic functional recovery and contractile reserve, which was accompanied by a lower recovery of tissue ATP content, without affecting cell viability. To this respect, reperfusion of ischemic hearts with high levels of fatty acids, which is seen in most clinically relevant conditions of ischemia, results in a rapid recovery of fatty acid oxidation [43]. It has been demonstrated that the increase in the mitochondrial acetyl $\mathrm{CoA} / \mathrm{CoA}$ and $\mathrm{NADH} / \mathrm{NAD}^{+}$ratios, caused by excessive rates of fatty acid oxidation during reperfusion, lead to the inhibition of PDH, due to the activation of PDH kinase (PDK) which phosphorylates and inactivates PDH, resulting in the reduction of pyruvate decarboxylation to acetyl-CoA and $\mathrm{CO}_{2}$ [59]. Consistent with this, in the present study data shows that when the atria were incubated with glucose and high levels of palmitate, PDH activity was significantly reduced during the reperfusion period. The resulting decrease in glucose oxidation, caused by an impaired coupling of glycolysis and glucose oxidation, might lead to the reduction of energy efficiency in terms of ATP produced $/ \mathrm{mol}$ of oxygen consumed [74]. To this respect, it is well known that fatty acid oxidation requires a greater rate of myocardial oxygen consumption for a given rate of ATP synthesis than do carbohydrates, causing a reduction of energy efficiency for basal metabolism and for generating contractile power [10, 35]. In addition to this, it has also been proposed that fatty acids waste ATP through the extrusion of long-chain fatty 
acids out of the mitochondria via uncoupling protein 3mediated futile cycle, possibly contributing to reduce myocardial ATP content $[29,70]$.

To confirm that myocardial energy substrate utilization is an important determinant of the ability of cardiac muscle to recovery after an ischemic episode, oxfenicine, an inhibitor of carnitine palmitoyl transferase-I, the rate-limiting enzyme for mitochondrial fatty acid uptake, was used in this study. Present results show that oxfenicine was able to reverse the harmful effects of fatty acids on functional recovery, suggesting that the deleterious effects of palmitate on the still viable myocardium may be the result of its oxidation. In these conditions, oxfenicine reverted partially the recovery of tissue ATP, reaching similar values to that observed when atria were incubated with glucose as sole exogenous substrate, supporting the existence of some relation between mitochondrial palmitate oxidation and the reduction of energy production, being this is consistent with a reduction of contractile function recovery.

To investigate the role of intrinsic AMPK activation on post-ischemic recovery, the enzyme was pharmacologically inhibited by the well-studied inhibitor compound $\mathrm{C}$, which was added to the bathing medium at the onset of simulated ischemia and maintained throughout the experiment. When AMPK was inhibited in the absence of palmitate, a decrease in the recovery of contractile reserve at the end of the reperfusion period was observed. These results were accompanied by a lower tissue ATP content recovery, suggesting that intrinsic AMPK activation contributes to myocardial cellular energy production and contractile function recovery when glucose is provided as sole exogenous substrate. To this regard, the beneficial role of AMPK activation observed in this study is consistent with the results obtained by other authors, in various ischemic-reperfused experimental models in the absence of high levels of fatty acids [11, 58, 66, 87]. The major previous study that correlated AMPK activity to reperfusion contractile function was carried out by Russel et al. The study demonstrated that hearts from transgenic mice expressing a kinase dead mutation of the $\alpha_{2}$ catalytic subunit of AMPK, perfused with glucose and physiological concentration of oleate, showed a reduced recovery of contractile function, which was associated with the inability to increase glucose uptake and utilization [66]. The fact that compound $\mathrm{C}$ led to similar contractile recovery during reperfusion when glucose was present as only exogenous substrate suggests that in the present experimental conditions, atria are able to cope with myocardial energy requirements despite decreased of ATP content. However, when myocardial energy demand rises in the presence of ISO, reduced ATP content recovery in the presence of compound $\mathrm{C}$ is likely to contribute to the depressed inotropic response.

In the present study, the atria subjected to Is-Rs in the presence of glucose as sole exogenous substrate showed that
PDH activity was enhanced when AMPK was activated, but it was reduced in the presence of AMPK inhibitor. These results suggest that an increase in mitochondrial oxidative decarboxylation of pyruvate to acetyl- $\mathrm{CoA}$ and $\mathrm{CO}_{2}$ could be taking place when AMPK is activated. Since AMPK increases cardiac glucose utilization, by the promotion of glucose uptake and glycolysis, pyruvate production might be enhanced. In this regard, it has been demonstrated that PDH activity is regulated by pyruvate [59]. High levels of pyruvate increase PDH activity, due in part to an inhibition of PDK, which as part of the PDH complex phosphorylates and inactivates PDH $[59,64]$. These conditions might contribute to increase pyruvate oxidation, resulting in higher ATP content restoration during reperfusion and therefore, contributing to contractile reserve recovery. Supporting these results, Bunger et al. reported that reperfusion of previously ischemic hearts with high concentrations of pyruvate improves the recovery of mechanical function, which was related to an increased oxidative flux because of PDH activation [9]. On the other hand, when glucose was used as sole exogenous substrate, oxfenicine reduced contractile reserve showing similar results to that observed in the experiments carried out in the presence of compound $\mathrm{C}$, suggesting that the beneficial effects of endogenous AMPK activation may also be, at least in part, due to enhancement of endogenous myocardial fatty acid oxidation. In the present experimental conditions, oxidation of endogenous fatty acid may not have the detrimental effects of high exogenous levels of fatty acids, contributing to mitochondrial energy production. To this regard, it has been suggested that intracellular fatty acids and triacylglycerol are important energy sources during reperfusion [18]. In the absence of exogenous fatty acids, it has been demonstrated that intracellular triacylglycerol oxidation increases during reperfusion, being this associated with improved functional recovery, suggesting that fatty acids derived from endogenous triacylglycerol do not contribute to reperfusion injury, as has been suggested for exogenous fatty acids [67].

Paradoxically, when atria were incubated with 1.2 $\mathrm{mM}$ palmitate, the inhibition of AMPK by compound C reverted the harmful effects exerted by this fatty acid, suggesting that intrinsic AMPK activation might be harmful for postischemic recovery when glucose and high levels of fatty acids are available as energy substrate. Supporting this, the limitation of palmitate oxidation through the addition of the pharmacological inhibitor of carnitine palmitoyl transferase-I to the bathing medium showed that contractile reserve and tissue ATP content recovery at the end of reperfusion improved, reaching similar values to those observed in the presence of compound $\mathrm{C}$. These results support the fact that harmful effects of AMPK during reperfusion when glucose and high levels of palmitate are available as exogenous substrates, may be due to enhancement of fatty acid oxidation rate. To this respect, during reperfusion, AMPK is thought to increase 
not only glucose utilization but also fatty acid oxidation. It has been proposed that AMPK regulates acetyl-CoA carboxylase activity by phosphorylation, which inhibits the enzyme and thus decreases the production of malonyl-CoA, an inhibitor of carnitine palmitoyl transferase-I $[80,81]$. In the presence of increased fatty acid oxidation rates during reperfusion, several studies have shown a reduction in glucose oxidation, at least in part, by the inhibition of the PDH complex due to an activation of PDK by increased intramitochondrial acetyl-CoA and $\mathrm{NADH} / \mathrm{NAD}^{+}$ratios, being this metabolic condition associated with poor functional recovery and a decrease in cardiac efficiency [40, 44, 45]. In this study, we demonstrated that AMPK inhibition reverted partially the effects of high levels of palmitate over PDH activity, suggesting that increased oxidation of fatty acids might be involved, at least in part, in the decreased PDH activity. Moreover, as glucose uptake and glycolysis are limited when endogenous AMPK activation is inhibited, the enhancement of PDH activity developed in the presence of glucose as sole exogenous substrate is only partially observed. The significance of these results is that in most clinically relevant conditions of reperfusion after ischemia, a high level of fatty acid is immediately detected. In this situation, intrinsic AMPK activation increases glucose uptake and glycolysis as well as fatty acid oxidation, but this condition might uncouple glycolysis to glucose oxidation. This situation leads to a reduction in cellular energetic production and functional recovery of myocardium subjected to ischemia-reperfusion, being AMPK activation detrimental for myocardium recovery after an ischemic period, when high levels of fatty acids are present as exogenous substrates. As AMPK effects are less well studied when high levels of fatty acids are provided as exogenous substrates, more studies are required to characterize the role of the enzyme in the ischemic-reperfused myocardium.

\section{Limitation of the study}

Pharmacologic inhibitors are useful reagents to probe the function of protein kinases in both cells and intact animals. Unfortunately, like many kinase inhibitors, several studies have reported that the widely used AMPK inhibitor compound C, may also inhibit other protein kinases, such as extracellular signal-regulated kinase 8 (ERK8), Src kinase and mitogen-activated protein kinase-interacting serine/threonine kinase 1 (MNK1). To this respect, although several observations has suggested a potential role for ERK8 in the regulation of DNA damage [34], its activation in ischemic-reperfused myocardium has not been reported. On the other hand, Src family of tyrosine kinase have been shown to mediate cellular responses to stress. However, the effect of myocardial ischemia on Src tyrosine kinases is unknown. It has been reported that Src tyrosine kinase inhibition might block the cardioprotection provided by ischemic preconditioning. To this respect, it has been suggested that Src might play an important role in the genesis of late preconditioning by serving as downstream elements of protein kinase C (PKC)-mediated signal transduction. Considerable evidence indicates that activation of PKC plays an important role in the development of ischemic preconditioning and that $\xi$ the isoform of $\mathrm{PKC}$ is specifically involved as an upstream signaling element. Nevertheless, the downstream effectors of the signaling transduction pathway in which PKC operates remain poorly defined $[3,60]$. Finally, it has been shown that MNK1 is the only isoform that can be activated by the p38-MAPK pathway in vivo. MNK1 has low basal activity in cells and is responsive to both stress and mitogen-stimulated pathways. MNK1 was found to be recruited to the eIF4F complex, the capinitiation complex that functions to bridge mRNA, the ribosome and the initiation translation machinery [20], making it a likely candidate kinase that mediates eIF4E phosphorylation. Although the biological significance of eIF4E phosphorylation is not completely understood [13, 51, 77], a slight decrease in eIF4E phosphorylation has been reported during global cerebral ischemia.

Although involvement of other mechanisms in the effects observed in the presence of compound $\mathrm{C}$ may not be discarded, various reports suggest that in specific circumstances compound C inhibits AMPK with expected results [78].

\section{Conclusion}

In conclusion, these results demonstrate that AMPK has a critical role in mediating the metabolic and functional responses of the heart to simulated ischemia and reperfusion. Taken together, these results support that intrinsic activation of AMPK has cardioprotective effects in the reperfused atria when glucose is the only available energetic substrate, but it results deleterious when palmitate is also available. Consequently, it appears that the role of AMPK during ischemia and reperfusion is dependent on the substrate availability and on the balance of the effects of AMPK on glucose and fatty acid metabolism.

Funding information This research was supported by grants from the University of Buenos Aires (UBACyT 20020130100309BA) and the Institute of Drug Chemistry and Metabolism (IQUIMEFA-CONICET).

\section{References}

1. Altschuld RA, Wenger WC, Lamka KG, Kindig OR, Capen CC, Mizuhira V, Vander Heide RS, Brierley GP (1985) Structural and functional properties of adult rat heart myocytes lysed with digitonin. J Biol Chem 260:14325-14334

2. An D, Pulinilkunnil T, Qi D, Ghosh S, Abrahani A, Rodrigues B (2005) The metabolic «switch» AMPK regulates cardiac heparinreleasable lipoprotein lipase. Am J Physiol Endocrinol Metab 288: E246-E253. https://doi.org/10.1152/ajpendo.00211.2004 
3. Baines CP, Wang L, Cohen MV, Downey JM (1998) Protein tyrosine kinase is downstream of protein kinase $\mathrm{C}$ for ischemic preconditioning's anti-infarct effect in the rabbit heart. J Mol Cell Cardiol 30:383-392. https://doi.org/10.1006/jmcc.1997.0601

4. Baron SJ, Li J, Russell RR, Neumann D, Miller EJ, Tuerk R, Wallimann T, Hurley RL, Witters LA, Young LH (2005) Dual mechanisms regulating AMPK kinase action in the ischemic heart. Circ Res 96:337-345. https://doi.org/10.1161/01.RES. 0000155723.53868.d2

5. Blackshaw JK, Fenwick DC, Beattie AW, Allan DJ (1988) The behaviour of chickens, mice and rats during euthanasia with chloroform, carbon dioxide and ether. Lab Anim 22:67-75

6. Blättler SM, Rencurel F, Kaufmann MR, Meyer UA (2007) In the regulation of cytochrome $\mathrm{P} 450$ genes, phenobarbital targets LKB1 for necessary activation of AMP-activated protein kinase. Proc Natl Acad Sci U S A 104:1045-1050. https://doi.org/10.1073/pnas. 0610216104

7. Blommaart EFC, Krause U, Schellens JPM, Vreeling-Sindelarova H, Meijer AJ (1997) The phosphatidylinositol 3-kinase inhibitors wortmannin and LY294002 inhibit autophagy in isolated rat hepatocytes. Eur J Biochem 243:240-246. https://doi.org/10.1111/j. 1432-1033.1997.0240a.x

8. Bradford MM (1976) A rapid and sensitive method for the quantitation of microgram quantities of protein utilizing the principle of protein-dye binding. Anal Biochem 72:248-254. https://doi.org/10. 1016/0003-2697(76)90527-3

9. Bünger R, Mallet RT, Hartman DA (1989) Pyruvate-enhanced phosphorylation potential and inotropism in normoxic and postischemic isolated working heart. Near-complete prevention of reperfusion contractile failure. Eur J Biochem 180:221-233

10. Burkhoff D, Weiss RG, Schulman SP, Kalil-Filho R, Wannenburg $T$, Gerstenblith G (1991) Influence of metabolic substrate on rat heart function and metabolism at different coronary flows. Am J Phys 261:H741-H750

11. Carvajal K, Zarrinpashneh E, Szarszoi O, Joubert F, Athea Y, Mateo P, Gillet B, Vaulont S, Viollet B, Bigard X, Bertrand L, VenturaClapier R, JA H (2007) Dual cardiac contractile effects of the alpha2-AMPK deletion in low-flow ischemia and reperfusion. Am J Physiol Heart Circ Physiol 292:H3136-H3147. https://doi.org/10. 1152/ajpheart.00683.2006

12. Christensen NJ, Videbaek J (1974) Plasma catecholamines and carbohydrate metabolism in patients with acute myocardial infarction. J Clin Invest 54:278-286. https://doi.org/10.1172/JCI107763

13. Clemens MJ, Bushell M, Jeffrey IW, Pain VM, Morley SJ (2000) Translation initiation factor modifications and the regulation of protein synthesis in apoptotic cells. Cell Death Differ 7:603-615. https://doi.org/10.1038/sj.cdd.4400695

14. Close B, Banister K, Baumans V, Bernoth E-M, Bromage N, Bunyan J, Erhardt W, Flecknell P, Gregory N, Hackbarth H, Morton D, Warwick C (1996) Recommendations for euthanasia of experimental animals: part 1. Lab Anim 30:293-316

15. Close B, Banister K, Baumans V, Bernoth EM, Bromage N, Bunyan J, Erhardt W, Flecknell P, Gregory N, Hackbarth H, Morton D, Warwick C (1997) Recommendations for euthanasia of experimental animals: part 2. DGXT of the European Commission. Lab Anim 31:1-32. https://doi.org/10.1258/ 002367797780600297

16. Darrabie MD, Arciniegas AJL, Mishra R, Bowles DE, Jacobs DO, Santacruz L (2011) AMPK and substrate availability regulate creatine transport in cultured cardiomyocytes. Am J Physiol Endocrinol Metab 300:E870-E876. https://doi.org/10.1152/ajpendo.00554.2010

17. Dennis SC, Gevers W, Opie LH (1991) Protons in ischemia: where do they come from; where do they go to? J Mol Cell Cardiol 23:1077-1086. https://doi.org/10.1016/0022-2828(91) 91642-5
18. Evans RD, Hauton D (2016) The role of triacylglycerol in cardiac energy provision. Biochim Biophys Acta Mol Cell Biol Lipids 1861:1481-1491. https://doi.org/10.1016/j.bbalip.2016.03.010

19. Garland PB, Randle PJ, Newsholme EA (1963) Citrate as an intermediary in the inhibition of phosphofructokinase in rat heart muscle by fatty acids, ketone bodies, pyruvate, diabetes and starvation. Nature 200:169-170. https://doi.org/10.1038/200169a0

20. Gingras A-C, Raught B, Sonenberg N (1999) eIF4 initiation factors: effectors of mRNA recruitment to ribosomes and regulators of translation. Annu Rev Biochem 68:913-963. https://doi.org/10. 1146/annurev.biochem.68.1.913

21. Golomb E, Schneider A, Houminer E, Dunnick J, Kissling G, Borman JB, Nyska A, Schwalb H (2007) occult cardiotoxicity: subtoxic dosage of bis(2-chloroethoxy)methane impairs cardiac response to simulated ischemic injury. Toxicol Pathol 35:383-387. https://doi.org/10.1080/01926230701230338

22. Green C (1987) Euthanasia. In: Tuffery AA (ed) Laboratory animals: an introduction for new experimenters. Wiley, Chichester, UK

23. Halse R, Fryer L, McCormack JD (2003) Regulation of glycogen synthase by glucose and glycogen. Diabetes 52:9-15

24. Handa N, Takagi T, Saijo S, Kishishita S, Takaya D, Toyama M, Terada T, Shirouzu M, Suzuki A, Lee S, Yamauchi T, Okada-Iwabu M, Iwabu M, Kadowaki T, Minokoshi Y, Yokoyama S (2011) Structural basis for compound $\mathrm{C}$ inhibition of the human AMPactivated protein kinase2 subunit kinase domain. Acta Crystallogr, Sect D Biol Crystallogr 67:480-487. https://doi.org/10.1107/ S0907444911010201

25. Hardie DG, Ross FA, Hawley SA (2012) AMPK: a nutrient and energy sensor that maintains energy homeostasis. Nat Rev Mol Cell Biol 13:251-262. https://doi.org/10.1038/nrm3311

26. Hawley SA, Davison M, Woods A, Davies SP, Beri RK, Carling D, Hardie DG (1996) Characterization of the AMP-activated protein kinase kinase from rat liver and identification of threonine 172 as the major site at which it phosphorylates AMP-activated protein kinase. J Biol Chem 271:27879-27887. https://doi.org/10.1074/ jbc.271.44.27879

27. Hearse DJ, Garlick PB, Humphrey SM (1977) Ischemic contracture of the myocardium: Mechanisms and prevention. Am J Cardiol 39: 986-993. https://doi.org/10.1016/S0002-9149(77)80212-9

28. Hermann R, Vélez DE, Rusiecki TM, M de las M FP, Mestre Cordero VE, Marina Prendes MG, Perazzo Rossini JC, Savino EA, Varela A (2015) Effects of 3-methyladenine on isolated left atria subjected to simulated ischaemia-reperfusion. Clin Exp Pharmacol Physiol 42:41-51. https://doi.org/10.1111/1440-1681.12323

29. Himms-Hagen J, Harper ME (2001) Physiological role of UCP3 may be export of fatty acids from mitochondria when fatty acid oxidation predominates: an hypothesis. Exp Biol Med 226:78-84

30. Ilic I, Stankovic I, Vidakovic R, Jovanovic V, Vlahovic Stipac A, Bi P, Neskovic AN (2015) Relationship of ischemic times and left atrial volume and function in patients with ST-segment elevation myocardial infarction treated with primary percutaneous coronary intervention. Int J Cardiovasc Imaging 31:709-716. https://doi.org/ 10.1007/s10554-015-0603-4

31. Kim E-K, Miller I, Aja S, Landree LE, Pinn M, McFadden J, Kuhajda FP, Moran TH, Ronnett GV (2004) C75, a fatty acid synthase inhibitor, reduces food intake via hypothalamic amp-activated protein kinase. J Biol Chem 279:19970-19976. https://doi.org/10. 1074/jbc.M402165200

32. King LM, Opie LH (1998) Glucose and glycogen utilisation in myocardial ischemia - changes in metabolism and consequences for the myocyte. Mol Cell Biochem 180:3-26. https://doi.org/10. 1023/A:1006870419309

33. Kingsley PB, Sako EY, Yang MQ, Zimmer SD, Ugurbil K, Foker JE, From AH (1991) Ischemic contracture begins when anaerobic glycolysis stops: a 31P-NMR study of isolated rat hearts. Am J Phys 261:H469-H478 
34. Klevernic IV, Martin NMB, Cohen P (2009) Regulation of the activity and expression of ERK8 by DNA damage. FEBS Lett 583:680-684. https://doi.org/10.1016/j.febslet.2009.01.011

35. Korvald C, Elvenes OP, Myrmel T (2000) Myocardial substrate metabolism influences left ventricular energetics in vivo. Am $\mathrm{J}$ Physiol Heart Circ Physiol 278:H1345-H1351

36. Kudo N, Barr AJ, Barr RL, Desai S, Lopaschuk GD (1995) High rates of fatty acid oxidation during reperfusion of ischemic hearts are associated with a decrease in malonyl-CoA levels due to an increase in 5'-AMP-activated protein kinase inhibition of acetylCoA carboxylase. J Biol Chem 270:17513-17520. https://doi.org/ 10.1074/jbc.270.29.17513

37. Kudo N, Gillespie JG, Kung L, Witters LA, Schulz R, Clanachan AS, Lopaschuk GD (1996) Characterization of 5'AMP-activated protein kinase activity in the heart and its role in inhibiting acetylCoA carboxylase during reperfusion following ischemia. Biochim Biophys Acta Lipids Lipid Metab 1301:67-75. https://doi.org/10. 1016/0005-2760(96)00013-6

38. Kurien VA, Oliver MF (1971) Free fatty acids during acute myocardial infarction. Prog Cardiovasc Dis 13:361-373. https://doi.org/ 10.1016/S0033-0620(71)80012-9

39. Lin Y-K, Lai M-S, Chen Y-C, Cheng C-C, Huang J-H, Chen S-A, Chen Y-J, Lin C-I (2012) Hypoxia and reoxygenation modulate the arrhythmogenic activity of the pulmonary vein and atrium. Clin Sci 122:121-132. https://doi.org/10.1042/CS20110178

40. Liu B, el Alaoui-Talibi Z, Clanachan a S, Schulz R, Lopaschuk GD (1996) Uncoupling of contractile function from mitochondrial TCA cycle activity and $\mathrm{MVO} 2$ during reperfusion of ischemic hearts. Am J Phys 270:H72-H80

41. Liu B, Clanachan AS, Schulz R, Lopaschuk GD (1996) Cardiac efficiency is improved after ischemia by altering both the source and fate of protons. Circ Res 79:940-948. https://doi.org/10.1161/ 01.RES.79.5.940

42. Lopaschuk GD (2008) AMP-activated protein kinase control of energy metabolism in the ischemic heart. Int J Obes 32:S29-S35. https://doi.org/10.1038/ijo.2008.120

43. Lopaschuk GD, Spafford MA, Davies NJ, Wall SR (1990) Glucose and palmitate oxidation in isolated working rat hearts reperfused after a period of transient global ischemia. Circ Res 66:546-553. https://doi.org/10.1161/01.RES.66.2.546

44. Lopaschuk GD, Collins-Nakai RL, Itoi T (1992) Developmental changes in energy substrate use by the heart. Cardiovasc Res 26: 1172-1180. https://doi.org/10.1093/cvr/26.12.1172

45. Lopaschuk GD, Wambolt RB, Barr RL (1993) An imbalance between glycolysis and glucose oxidation is a possible explanation for the detrimental effects of high levels of fatty acids during aerobic reperfusion of ischemic hearts. J Pharmacol Exp Ther 264:135-144

46. Lopaschuk GD, Collins-Nakai R, Olley PM, Montague TJ, McNeil G, Gayle M, Penkoske P, Finegan BA (1994) Plasma fatty acid levels in infants and adults after myocardial ischemia. Am Heart J 128:61-67. https://doi.org/10.1016/0002-8703(94)90010-8

47. Lowry OH, Rosebrough NJ, Farr AL, Randall RJ (1951) Protein measurement with the Folin phenol reagent. J Biol Chem 193:265275. https://doi.org/10.1016/0304-3894(92)87011-4

48. Marsin AS, Bertrand L, Rider MH, Deprez J, Beauloye C, Vincent MF, Van den Berghe G, Carling D, Hue L (2000) Phosphorylation and activation of heart PFK-2 by AMPK has a role in the stimulation of glycolysis during ischaemia. Curr Biol 10:1247-1255. https://doi.org/10.1016/S0960-9822(00)00742-9

49. Mccullough LD, Zeng Z, Li H, Landree LE, Mcfadden J, Ronnett G V (2005) Pharmacological Inhibition of AMP-activated protein kinase provides neuroprotection in stroke*. https://doi.org/10.1074/ jbc.M409985200

50. Momcilovic M, Hong SP, Carlson M (2006) Mammalian TAK1 activates Snfl protein kinase in yeast and phosphorylates AMP- activated protein kinase in vitro. J Biol Chem 281:25336-25343. https://doi.org/10.1074/jbc.M604399200

51. Morley SJ, Naegele S (2002) phosphorylation of eukaryotic initiation factor (eif) $4 \mathrm{e}$ is not required for de novo protein synthesis following recovery from hypertonic stress in human kidney cells. J Biol Chem 277:32855-32859. https://doi.org/10.1074/jbc. C200376200

52. Morrison A, Chen L, Wang J, Zhang M, Yang H, Ma Y, Budanov A, Lee JH, Karin M, Li J (2015) Sestrin2 promotes LKB1-mediated AMPK activation in the ischemic heart. FASEB J 29:408-417. https://doi.org/10.1096/fj.14-258814

53. Mueller HS, Ayres SM (1980) Propranolol decreases sympathetic nervous activity reflected by plasma catecholamines during evolution of myocardial infarction in man. J Clin Invest 65:338-346. https://doi.org/10.1172/JCI109677

54. Nichols CG, Lederer WJ (1990) The role of ATP in energydeprivation contractures in unloaded rat ventricular myocytes. Can J Physiol Pharmacol 68:183-194

55. Oakhill JS, Steel R, Chen Z-P, Scott JW, Ling N, Tam S, Kemp BE (2011) AMPK is a direct adenylate charge-regulated protein kinase. Science 332:1433-1435. https://doi.org/10.1126/science.1200094

56. Opie LH (2008) Metabolic management of acute myocardial infarction comes to the fore and extends beyond control of hyperglycemia. Circulation 117:2172-2177. https://doi.org/10.1161/ CIRCULATIONAHA.108.780999

57. Pacchia CF, Dosdall DJ, Ranjan R, DiBella E (2014) Alterations in atrial perfusion during atrial fibrillation. Exp Physiol 99:12671272. https://doi.org/10.1113/expphysiol.2014.080242

58. Paiva MA, Gonçalves LM, Providência LA, Davidson SM, Yellon DM, Mocanu MM (2010) Transitory activation of AMPK at reperfusion protects the ischaemic-reperfused rat myocardium against infarction. Cardiovasc Drugs Ther 24:25-32. https://doi.org/10. 1007/s10557-010-6222-3

59. Patel MS, Nemeria NS, Furey W, Jordan F (2014) The pyruvate dehydrogenase complexes: Structure-based function and regulation. J Biol Chem 289:16615-16623. https://doi.org/10.1074/jbc. R114.563148

60. Ping P, Zhang J, Zheng YT, Li RC, Dawn B, Tang XL, Takano H, Balafanova Z, Bolli R (1999) Demonstration of selective protein kinase C-dependent activation of Src and Lck tyrosine kinases during ischemic preconditioning in conscious rabbits. Circ Res 85: 542-550. https://doi.org/10.1161/01.RES.85.6.542

61. Piper HM, Abdallah Y, Schäfer C (2004) The first minutes of reperfusion: a window of opportunity for cardioprotection. Cardiovasc Res 61:365-371. https://doi.org/10.1016/j.cardiores. 2003.12.012

62. Ramirez AM, Demeestere K, De Belie N, Mäntylä T, Levänen E (2010) Titanium dioxide coated cementitious materials for air purifying purposes: preparation, characterization and toluene removal potential. Build Environ 45:832-838. https://doi.org/10.1016/j. buildenv.2009.09.003

63. Randle PJ, Garland PB, Newsholmet EA, Hales CN (1965) The glucose fatty acid cycle in obesity and maturity onset diabetes mellitus. Ann N Y Acad Sci 131:324-333. https://doi.org/10.1111/ j.1749-6632.1965.tb34800.x

64. Roche TE, Baker JC, Yan X, Hiromasa Y, Gong X, Peng T, Dong J, Turkan a KS a (2001) Distinct regulatory properties of pyruvate dehydrogenase kinase and phosphatase isoforms. Prog Nucleic Acid Res Mol Biol 70:33-75. https://doi.org/10.1016/S00796603(01)70013-X

65. Rodríguez-Calvo R, Vázquez-Carrera M, Masana L, Neumann D (2015) AICAR protects against high palmitate/high insulin-induced intramyocellular lipid accumulation and insulin resistance in HL-1 cardiac cells by inducing PPAR-target gene expression. PPAR Res 2015:785783. https://doi.org/10.1155/2015/785783 
66. Russell RR, Li J, Coven DL, Pypaert M, Zechner C, Palmeri M, Giordano FJ, Mu J, Birnbaum MJ, Young LH (2004) AMPactivated protein kinase mediates ischemic glucose uptake and prevents postischemic cardiac dysfunction, apoptosis, and injury. J Clin Invest 114:495-503. https://doi.org/10.1172/JCI200419297

67. Saddik M, Lopaschuk GD (1992) Myocardial triglyceride turnover during reperfusion of isolated rat hearts subjected to a transient period of global ischemia. J Biol Chem 267:3825-3831

68. Sambandam N, Lopaschuk GD (2003) AMP-activated protein kinase (AMPK) control of fatty acid and glucose metabolism in the ischemic heart. Prog Lipid Res 42:238-256. https://doi.org/10. 1016/S0163-7827(02)00065-6

69. Samovski D, Su X, Xu Y, Abumrad NA, Stahl PD (2012) Insulin and AMPK regulate FA translocase/CD36 plasma membrane recruitment in cardiomyocytes via Rab GAP AS160 and Rab8a Rab GTPase. J Lipid Res 53:709-717. https://doi.org/10.1194/jlr. M023424

70. Schrauwen P (2001) An alternative function for human uncoupling protein 3: protection of mitochondria against accumulation of nonesterified fatty acids inside the mitochondrial matrix. FASEB J 15: 2497-2502. https://doi.org/10.1096/fj.01-0400hyp

71. Schwenk RW, Dirkx E, Coumans WA, Bonen A, Klip A, Glatz JFC, Luiken JJFP (2010) Requirement for distinct vesicleassociated membrane proteins in insulin- and AMP-activated protein kinase (AMPK)-induced translocation of GLUT4 and CD36 in cultured cardiomyocytes. Diabetologia 53:2209-2219. https://doi. org/10.1007/s00125-010-1832-7

72. Shimojo N, Fujino K, Kitahashi S, Nakao M, Naka K, Okuda K (1991) Lactate analyzer with continuous blood sampling for monitoring blood lactate during physical exercise. Clin Chem 37:1978-1980

73. Solem L (1993) Selective activation of the sodium-independent, cyclosporine A-sensitive calcium pore of cardiac mitochondria by doxorubicin. Toxicol Appl Pharmacol 121:50-57. https://doi.org/ 10.1006/taap.1993.1128

74. Stanley WWC, F a R, Lopaschuk GD (2005) Myocardial substrate metabolism in the normal and failing heart. Physiol Rev 85:10931129. https://doi.org/10.1152/physrev.00006.2004

75. Takagi H, Matsui Y, Hirotani S, Sakoda H, Asano T, Sadoshima J (2007) AMPK mediates autophagy during myocardial ischemia in vivo. Autophagy 3:405-407. https://doi.org/10.4161/auto.4281

76. Takagi H, Matsui Y, Sadoshima J (2007) The role of autophagy in mediating cell survival and death during ischemia and reperfusion in the heart. Antioxid Redox Signal 9:1373-1381. https://doi.org/ 10.1089/ars.2007.1689

77. Ueda T, Watanabe-Fukunaga R, Fukuyama H, Nagata S, Fukunaga R (2004) Mnk2 and Mnk1 are essential for constitutive and inducible phosphorylation of eukaryotic initiation factor $4 \mathrm{E}$ but not for cell growth or development. Mol Cell Biol 24:6539-6549. https:// doi.org/10.1128/MCB.24.15.6539-6549.2004
78. Viollet B, Horman S, Leclerc J, Lantier L, Foretz M, Billaud M, Giri S, Andreelli F (2010) AMPK inhibition in health and disease. Crit Rev Biochem Mol Biol 45:276-295. https://doi.org/10.3109/ 10409238.2010.488215

79. van der Vusse GJ, Stam H (1987) Lipid and carbohydrate metabolism in the ischaemic heart. Basic Res Cardiol 82(Suppl 1):149-153

80. Witters LA, Gao G, Kemp BE, Quistorff B (1994) Hepatic 5'-AMPactivated protein kinase: zonal distribution and relationship to acetyl-CoA carboxylase activity in varying nutritional states. Arch Biochem Biophys 308:413-419. https://doi.org/10.1006/abbi. 1994.1058

81. Woods A, Munday MR, Scott J, Yang X, Carlson M, Carling D (1994) Yeast SNF1 is functionally related to mammalian AMPactivated protein kinase and regulates acetyl-CoA carboxylase in vivo. J Biol Chem 269:19509-19515. https://doi.org/10.1073/ pnas. 051042298

82. Woods A, Johnstone SR, Dickerson K, Leiper FC, Fryer LGD, Neumann D, Schlattner U, Wallimann T, Carlson M, Carling D (2003) LKB1 is the upstream kinase in the AMP-activated protein kinase cascade. Curr Biol 13:2004-2008. https://doi.org/10.1016/j. cub.2003.10.031

83. Woods A, Dickerson K, Heath R, Hong S-P, Momcilovic M, Johnstone SR, Carlson M, Carling D (2005) Ca2+/calmodulin-dependent protein kinase kinase- $\beta$ acts upstream of AMP-activated protein kinase in mammalian cells. Cell Metab 2:21-33. https://doi. org/10.1016/j.cmet.2005.06.005

84. Xiao B, Sanders MJ, Underwood E, Heath R, Mayer FV, Carmena D, Jing C, Walker PA, Eccleston JF, Haire LF, Saiu P, Howell SA, Aasland R, Martin SR, Carling D, Gamblin SJ (2011) Structure of mammalian AMPK and its regulation by ADP. Nature 472:230233. https://doi.org/10.1038/nature09932

85. Xing Y, Musi N, Fujii N, Zou L, Luptak I, Hirshman MF, Goodyear LJ, Tian R (2003) Glucose metabolism and energy homeostasis in mouse hearts overexpressing dominant negative $\alpha 2$ subunit of AMP-activated protein kinase. J Biol Chem 278:28372-28377. https://doi.org/10.1074/jbc.M303521200

86. Zaha VG, Young LH (2012) AMP-activated protein kinase regulation and biological actions in the heart. Circ Res 111:800-814. https://doi.org/10.1161/CIRCRESAHA.111.255505

87. Zarrinpashneh E, Carjaval K, Beauloye C, Ginion A, Mateo P, Pouleur A-C, Horman S, Vaulont S, Hoerter J, Viollet B, Hue L, Vanoverschelde J-L, Bertrand L (2006) Role of the 2-isoform of AMP-activated protein kinase in the metabolic response of the heart to no-flow ischemia. AJP Heart Circ Physiol 291:H2875-H2883. https://doi.org/10.1152/ajpheart.01032.2005

88. Zhou G, Myers R, Li Y, Chen Y, Shen X, Fenyk-Melody J, Wu M, Ventre J, Doebber T, Fujii N, Musi N, Hirshman MF, Goodyear LJ, Moller DE (2001) Role of AMP-activated protein kinase in mechanism of metformin action. J Clin Invest 108:1167-1174. https:// doi.org/10.1172/JCI200113505 